\title{
Analysis of Mineral Aerosol in the Surface Layer over the Caspian Lowland Desert by the Data of 12 Summer Field Campaigns in 2002-2020
}

\author{
Otto G. Chkhetiani ${ }^{1, * \mathbb{D}}$, Natalia V. Vazaeva ${ }^{1,2}$, Alexander V. Chernokulsky ${ }^{1} \mathbb{D}, \operatorname{Karim}$ A. Shukurov ${ }^{1}$, \\ Dina P. Gubanova ${ }^{1}$ (D), Maria S. Artamonova ${ }^{1}$, Leonid O. Maksimenkov ${ }^{1}$, Fedor A. Kozlov ${ }^{1,3}$ \\ and Tatyana M. Kuderina ${ }^{4}$ \\ 1 A.M. Obukhov Institute of Atmospheric Physics, RAS, Pyzhyovskiy Pereulok, 3, 109017 Moscow, Russia; \\ vazaevanv@ifaran.ru (N.V.V.); a.chernokulsky@ifaran.ru (A.V.C.); karim.shukurov@ifaran.ru (K.A.S.); \\ dgubanova@mail.ru (D.P.G.); martamonova@gmail.com (M.S.A.); leonidmax@gmail.com (L.O.M.); \\ fed_ko_95@mail.ru (F.A.K.) \\ 2 Power Engineering Department, Bauman Moscow State Technical University, 5 s.1 2-yay Baumanskaya ul, \\ 105005 Moscow, Russia \\ 3 Faculty of Geography, Lomonosov Moscow State University, GSP-1, Leninskie Gory, 119991 Moscow, Russia \\ 4 Institute of Geography, RAS, Staromonetniy Lane. 29, 119017 Moscow, Russia; tmkud@yandex.ru \\ * Correspondence: ochkheti@gmail.com
}

Citation: Chkhetiani, O.G.; Vazaeva, N.V.; Chernokulsky, A.V.; Shukurov, K.A.; Gubanova, D.P.; Artamonova, M.S.; Maksimenkov, L.O.; Kozlov, F.A.; Kuderina, T.M. Analysis of Mineral Aerosol in the Surface Layer over the Caspian Lowland Desert by the Data of 12 Summer Field Campaigns in 2002-2020. Atmosphere 2021, 12, 985. https://doi.org/ $10.3390 /$ atmos 12080985

Academic Editors: Georgy Golitsyn and Liwu Zhang

Received: 22 May 2021

Accepted: 27 July 2021

Published: 30 July 2021

Publisher's Note: MDPI stays neutral with regard to jurisdictional claims in published maps and institutional affiliations.

Copyright: (c) 2021 by the authors. Licensee MDPI, Basel, Switzerland. This article is an open access article distributed under the terms and conditions of the Creative Commons Attribution (CC BY) license (https:// creativecommons.org/licenses/by/ $4.0 /)$.

\begin{abstract}
In-situ knowledge on characteristics of mineral aerosols is important for weather and climate prediction models, particularly for modeling such processes as the entrainment, transport and deposition of aerosols. However, field measurements of the dust emission flux, dust size distribution and its chemical composition under realistic wind conditions remain rare. In this study, we present experimental data over annual expeditions in the arid and semi-arid zones of the Caspian Lowland Desert (Kalmykia, south of Russia); we evaluate characteristics of mineral aerosol concentration and fluxes, estimate its chemical composition and calculate its long-distance transport characteristics. The mass concentration in different years ranges from several tens to several hundred of $\mu \mathrm{g} \mathrm{m}^{-3}$. The significant influence of wind velocity on the value of mass and counting concentration and on the proposed entrainment mechanisms is confirmed. An increased content of anthropogenic elements ( $\mathrm{S}, \mathrm{Sn}, \mathrm{Pb}, \mathrm{Bi}, \mathrm{Mo}, \mathrm{Ag}, \mathrm{Cd}, \mathrm{Hg}$, etc.), which is characteristic for all observation points in the south of the European Russia, is found. The trajectory analysis show that long-range air particles transport from the Caspian Lowland Desert to the central regions of European Russia tends to increase in the recent decades.
\end{abstract}

Keywords: mineral aerosol; emission; aerosol transport; field measurements; aerosol composition; satellite data; atmospheric boundary layer; European arid lands; south of Russia

\section{Introduction}

Mineral aerosol is the most common one among various aerosol species. It contributes more than half of the global aerosol amount [1-3]. In arid zones, the degree of impact of surface aerosol on geochemical, ecological, and radiation-climatic processes increases. The mineral particles, emitted particularly due to dust storms, comprise the organic matter and nutrients and may be transported horizontally over a long distance. This leads to land degradation because of structure and compositional changes of the soils both at dust sources and at dust receptors and to changes in biogeochemical cycles over land and ocean [4-9], to loss to public utilities because of reduced visibility [10-12] and air pollution $[4,5,8,9,13,14]$, and even to global environmental [15] and climate changes because of aerosol direct influence on radiation fluxes $[4,8,13,16]$, cloud formation [12,17], vegetation productivity [7,9], glacier and snow cover albedo [17], and atmospheric electricity [11]. 
Much has been achieved since Bagnold published his work "The Physics of Blown Sand and Desert Dunes" in 1941 [18]. However, the characteristics determining the quantity of dust emitted are not completely understood yet due to their chemical and physical complexity, the difficulty of observation, and the lack of predictive and monitoring tools at different spatiotemporal scales.

Satellite observations provide relatively good spatial coverage, high sampling frequency, and considerably high accuracy, which make them suitable for dust storms monitoring in different areas [19-23]. However, the spatial resolution of satellite imagery is still low as well as time series of the retrieved optical properties are too short [19-26]. In turns, the in-situ measurements allow to determine the relationship between the vertical dust mass flux and wind velocity, particularly, friction velocity [27-29].

In general, a mathematical modelling according to some field measurements provides (in the best case) the semi-empirical formulae for the particular specific regions under particular weather conditions. The number of dust emission models is based on field experiments [30-36]. The empirical coefficients used in these models are expected to vary with the type of the eroded soil, particle size distribution (PSD) of emitted dust and weather conditions. However, it is difficult to determine these coefficients either experimentally or theoretically. The most reliable way is using data sets of experimental measurements under variety of conditions.

It is known [5,35] that dust entrainment, transport and deposition are governed by four main factors: atmospheric conditions (wind, precipitation, stratification, etc.), soil state (composition, texture, etc.), land-surface characteristics (topography, soil moisture, vegetation and non-erodible elements, surface roughness, etc.), land management practice (farming, grazing and mining, etc.).

The commonly modes for particles driven by the wind [37] are: suspension (mostly for particles smaller than $60 \mu \mathrm{m}$ in diameter), saltation (mostly for particles of 60-2000 $\mu \mathrm{m}$ in diameter) and traction (rolling, sliding, surface creep, pushing of particles along the surface). The particles too large to be gone with the wind by mere suspension, start to roll or fly into the air at the moment when friction velocity over some threshold velocity and then the particles fall back to the surface where they bombard other particles and bounce back into the air. This movement is known as saltation and may involves other grains into the motion that leads to a cascading effect.

Up to now there are more than eight different theoretical hypotheses describing the complex mechanism of sand particles entrainment [38]. They include the contact force entrainment hypotheses (inclined flying hypothesis, the saltation impact hypothesis, and the vibration hypothesis) and the aerodynamic force hypotheses (buoyancy force hypothesis, the aerodynamic drag hypothesis, the turbulence hypothesis, the negative pressure hypothesis and the vortex hypothesis). The particle entrainment influences greatly on PSD.

Dust PSD at emission is a significant point to evaluate in dust studies. In some situation, the indicators of the entrainment process vary strongly from case to case, relying on a variety of factors, but specifically on particle size [39]. Gillette [40] confirmed that dust emission can be produced by aerodynamic lift and saltation bombardment. Shao et al. [41] explained that aerosol flux due to aerodynamic-lift emission is much weaker than the one due to saltation-bombardment emission. Sow et al. [42] indicated that the PSD proved to be independent of friction velocity, while Khalfallah et al. [43] stated that emission-flux PSD depends on atmospheric boundary layer (ABL) stability. Shao et al. [39] reported that dust PSD depends on friction velocity and on ABL stability, and both of the reason related to enhanced saltation bombardment in convective turbulent flows. In general, he showed that dust PSD depends on saltation bombardment and inter-particle cohesion. The friction velocity is a measure of wind shear at the surface, and the threshold friction velocity defines the minimum friction velocity required for emission to occur.

Present-day models are based on saltation bombardment as the main mechanism for dust and aerosol production. Nevertheless, the airborne-dust PSD measurements of Rosen- 
berg et al. [44] and airborne number concentration measurements of Gorchakov et al. [45] showed a larger fraction of fine particles than if it was generated by saltation only. Measurements in deserts clearly confirm the presence of mineral dust in the ABL under windless and low-wind conditions not sufficient enough for initiation of saltation mechanism [46,47]. Khalfallah et al. [43] in their study found an empirical correlation between this PSD and the thermal structure of the surface ABL. The mass concentrations of fine aerosol obtained for fluid dynamic parameters in the viscous thermal boundary layer near the ground surface are related to a temperature drop in the thermal layer at the surface and from the values of friction velocity-so called non-saltation emission [48]. For sufficiently coarse particles, the Convective Turbulent Dust Emission model $[35,36,49]$ is widespread. For fine particles $\left(\mathrm{PM}_{1.5} / \mathrm{PM}_{2.0}\right)$, authors were successful in using non-saltation model $[48,50]$. The extensive investigation of PSD in this particular area was performed in [51].

Long-term series of dust mainly comes from the ground visibility observation at meteorological stations and used for research on dust storms and spatio-temporal distribution characteristics of entrained aerosols [52-54]. However, data of fixed meteorological station alone is often not enough for mathematical modelling of dust emission; moreover, there are many areas without meteorological stations at all. In this regard, the annual expeditions to arid and semi-arid zones of the Caspian Lowland Desert may be useful for progress in that field. Dust storms are a serious environmental problem in arid and semi-arid regions of the Caspian Lowland. This region is easily eroded due to its underlying surface (common in arid zones) and meteorological features with typical wind and temperature gradient strong enough to entrainment the particles. Such experimental data sets are also essential for validation against various numerical simulation findings performed in the frame of this particular region.

The number of large-scale field experiments have been recently carried out (in [55] for Russia; in [35] the examples are ADEC [56], and ACE-Asia [57,58]), and the networks for obtaining aerosol (including dust) characteristics over large areas have been constructed. For example, among the latter is the AErosol RObotic NETwork (AERONET) - a federation of ground-based remote sensing aerosol networks (including over 150 stations), that evaluate aerosol optical properties (spectral aerosol optical depth, single scattering albedo, Angstrom parameter, aerosol scattering function, particle size distribution and others) in atmospheric column and validates satellite data retrievals of similar aerosol parameters.

In this paper, the direct observations of mineral dust aerosol within the range from 0.15 to $15 \mu \mathrm{m}$ were carried out on arid and semi-arid zones of Kalmykia (Caspian Lowland, South of Russia) during summer 12 expeditions in 2002-2020 under different wind conditions with and without saltation process. The campaigns were carried out mostly during the period of maximum temperature and humidity. The description of the experimental site and the details of the instrumentation and methods are given in the following 'Materials and methods' section.

The aerosol optical depth (AOD) time series retrieved from the data of the EUMETSATCMSAF product based on the SEVIRI instrument on the METEOSAT satellite [59] (see Section 2.2.1) are analyzed. We use field campaigns' data in the context of long-term changes from satellite data and from meteorological data to determine the campaigns' date and duration, and to investigate whether aerosol characteristics are typical or exceptional for the region of interest. Accordingly, the campaigns were carried out mostly during the period of maximum temperature and humidity.

The complex and detailed results of expeditional data are discussed in the "Results and Discussion" Section. The study of dust emission including the analysis of the aerosol mass concentration and the aerosol flux, its chemical composition under realistic wind conditions is described in Sections 3.1 and 3.2.

The fine aerosol contributes greatly to the total aerosol content of the atmospheric surface layer. The surface air layer over the arid region of Kalmykia is characterized an increased aerosol emission during the observation period that may contribute to the longrange aerosol transport from the $\mathrm{ABL}$ over the arid territories to remoted regions. Fine 
particles suspended in air with the chemical composition and concentration related to those described in Sections 3.1 and 3.2 can be transported over long paths and form the aerosol layers which greatly influenced to the radiation and energy balance. Consequently, it is of the utmost importance to study the probability of such a transport of air particles (potentially polluted with dust), that reflects the potential transport of atmospheric pollutants. It is discussed in Section 3.3.

The conclusions are given in the Section 4 .

\section{Materials and Methods}

\subsection{Site Description}

The experiment was carried out in south of Russia (Caspian Lowland, Kalmykia) in the summer periods of 2002, 2003, 2004, 2007, 2009, 2010, 2011, 2013, 2014, 2016, 2018, and 2020. The duration and timing of the field campaigns are shown in Tables 1 and 2.

Table 1. Duration and timing of the field campaigns.

\begin{tabular}{ccccccccccccc}
\hline Year & $\mathbf{2 0 0 2}$ & $\mathbf{2 0 0 3}$ & $\mathbf{2 0 0 4}$ & $\mathbf{2 0 0 7}$ & $\mathbf{2 0 0 9}$ & $\mathbf{2 0 1 0}$ & $\mathbf{2 0 1 1}$ & $\mathbf{2 0 1 3}$ & $\mathbf{2 0 1 4}$ & $\mathbf{2 0 1 6}$ & $\mathbf{2 0 1 8}$ & $\mathbf{2 0 2 0}$ \\
\hline \multirow{2}{*}{ Days } & $18.06-26.06$, & $28.06-$ & $29.06-$ & $20.07-$ & $19.07-$ & $17.07-$ & $20.07-$ & $17.07-$ & $22.07-$ & $19.07-$ & $23.07-$ & $21.07-$ \\
& $28.06-10.07$ & 10.07 & 04.07 & 31.07 & 27.07 & 20.07 & 29.07 & 28.07 & 31.07 & 30.07 & 03.08 & 01.08 \\
\hline
\end{tabular}

Table 2. Processed data of the field campaigns. "+" denotes the days for which the data have been processed; "-" denotes the days for which the data have not been processed yet.

\begin{tabular}{|c|c|c|c|c|c|c|c|c|c|c|c|c|c|c|c|c|c|c|c|c|c|c|c|c|c|c|c|c|c|}
\hline \multirow{2}{*}{$\begin{array}{c}\text { Month } \\
\text { Day }\end{array}$} & \multicolumn{13}{|c|}{ June } & \multicolumn{13}{|c|}{ July } & \multicolumn{3}{|c|}{ August } \\
\hline & 23 & 24 & 25 & 26 & 27 & 28 & 29 & 30 & 1 & 2 & 3 & 4 & 18 & 19 & 20 & 21 & 22 & 23 & 24 & 25 & 26 & 27 & 28 & 29 & 30 & 31 & 1 & 2 & 3 \\
\hline 2002 & + & + & + & + & - & - & - & - & - & - & - & - & - & - & - & - & - & - & - & - & - & - & - & - & - & - & - & - & - \\
\hline 2003 & - & - & - & + & + & + & + & + & + & + & + & - & - & - & - & - & - & - & - & - & - & - & - & - & - & - & - & - & - \\
\hline 2004 & - & - & - & - & - & - & + & + & - & + & + & + & - & - & - & - & - & - & - & - & - & - & - & - & - & - & - & - & - \\
\hline 2007 & - & - & - & - & - & - & - & - & - & - & - & - & - & - & - & - & - & + & + & + & + & + & + & + & + & + & - & - & - \\
\hline 2009 & - & - & - & - & - & - & - & - & - & - & - & - & - & - & + & + & + & + & + & + & + & + & - & - & - & - & - & - & - \\
\hline 2010 & - & - & - & - & - & - & - & - & - & - & - & - & + & + & + & - & - & - & - & - & - & - & - & - & - & - & - & - & - \\
\hline 2011 & - & - & - & - & - & - & - & - & - & - & - & - & - & - & + & + & + & + & + & + & + & + & + & + & - & - & - & - & - \\
\hline 2013 & - & - & - & - & - & - & - & - & - & - & - & - & + & - & - & + & + & + & + & + & + & + & - & - & - & - & - & - & - \\
\hline 2014 & - & - & - & - & - & - & - & - & - & - & - & - & - & - & - & - & + & + & + & + & + & + & + & + & + & + & - & - & - \\
\hline 2016 & - & - & - & - & - & - & - & - & - & - & - & - & - & + & + & + & + & + & + & + & + & + & + & + & - & - & - & - & - \\
\hline 2018 & - & - & - & - & - & - & - & - & - & - & - & - & - & - & - & - & - & - & - & - & - & - & - & - & - & - & + & + & + \\
\hline 2020 & - & - & - & - & - & - & - & - & - & - & - & - & - & - & - & - & + & + & + & + & + & + & + & + & + & + & - & - & - \\
\hline
\end{tabular}

The site, described in more details in $[48,60]$, is located in the arid region. A map of the experimental field observation stations in Kalmykia is shown in Figure 1 (see also [61] for detailed map).

Description of the underlying surface (landscapes of Kalmykia and the Black Lands): the mosaic of the landscape cover includes dry-steppe landscapes (vegetation: Artemisia alba, Artemisia austriaca, a projective cover of $60-80 \%$ ) with Solonchaks and very dynamic anthropogenic sand massifs, which in dry years occupy up to a quarter of the territory of Kalmykia.

\subsection{Measurements}

It is known, that there are difficulties in measuring emission-dust PSD, and it approximated using airborne-dust PSD measured at some, often different, heights [39,62]. In our study, we use the "gradient method" [43], which was designed by Gillette et al. [63] with the use of an Optical Particle Counter for measuring aerosol flux.

The required instrumentation deployed during the field experiments and methods are described in this paragraph. 


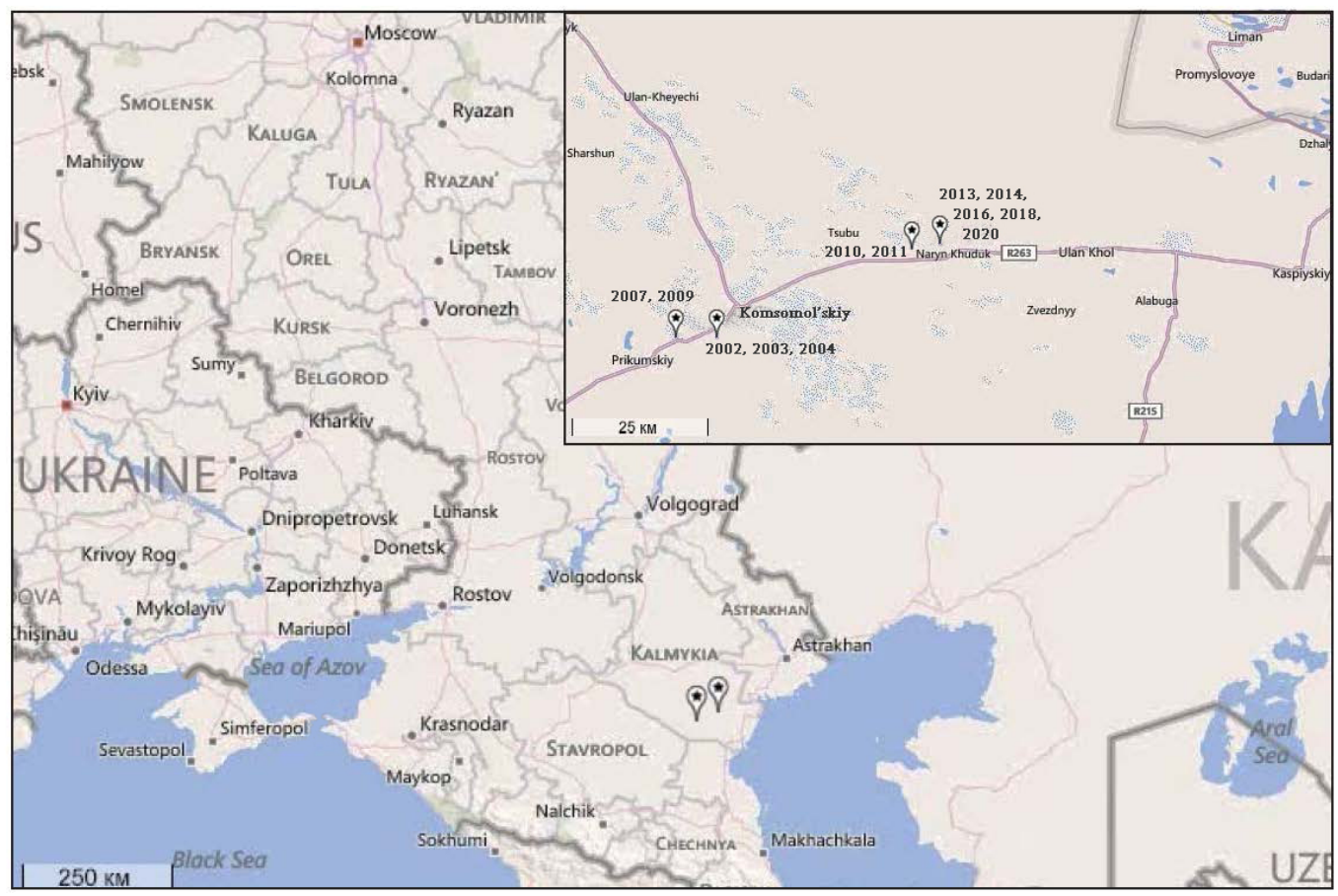

Figure 1. Map of experimental field observation stations (1-4) located in Kalmykia in 2002-2020.

\subsubsection{Weather Conditions}

Wind velocity, air temperature, pressure and humidity were measured continuously and simultaneously at levels of $0.2,0.5,1.0,2.0,3.0$, and $5.0 \mathrm{~m}$. Additionally, the five sensors of humidity and temperature of the surface were placed in the vicinity of the base of aerosol particle counters within the distance of 1-2 $\mathrm{m}$ [48]. Wind direction was measured with a sonic anemometer, fluctuations in three wind-velocity components and air temperature were measured with an USA-1 (METEK). The measuring instrument was constructed on the basis of AANDERAA Data Instruments' sensors. The east wind orientation in amplitude is predominant over the observation period (Figure 2).

With a general low variability of the monthly amount of precipitation, the simultaneous extension of both rainy and rainless periods, with a general increase in temperature (Figure 3), can contribute to the formation of droughts (in rainless periods), leading to more probable dust storms. However, according to the station data [64], this increase is insignificant. Only the linear trend of air temperature is well pronounced: the growth in temperature linked to global warming points the increasing trend of about $0.5^{\circ} \mathrm{C} /$ decade since 1960 to 2020 (Figure 3).

The campaigns were carried out mostly during the summer period when the maximum in the temperature and humidity occur (Figure 4).

We also used satellite data to estimate whether date of field campaigns and hence aerosol characteristics were typical or exceptional for the region of interest. In particular, we analyzed the daily variability of the aerosol optical thickness (depth) (AOD) in the arid region of the south of the European territory of Russia $\left(45-48^{\circ} \mathrm{N}, 43-47^{\circ} \mathrm{E}\right)$ using the CMSAF product for AOD (at a wavelength of $550 \mathrm{~nm}$ ). These products are based on the SEVIRI instrument installed on the METEOSAT geostationary satellite (till 2012 year). 


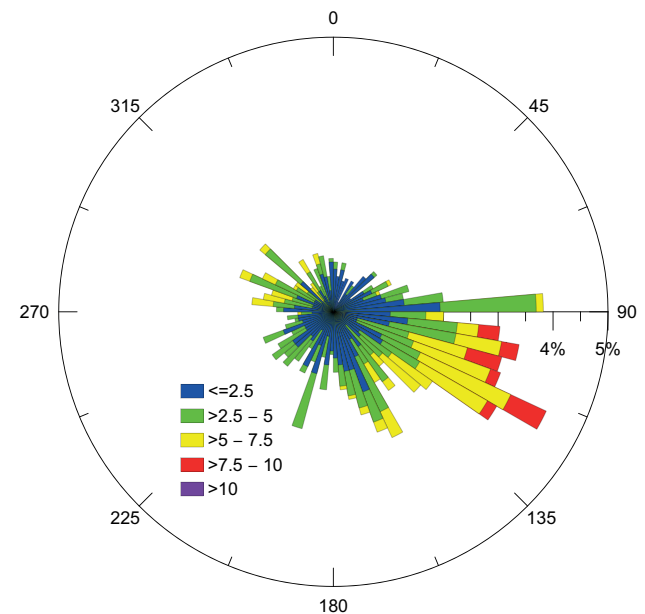

(a)

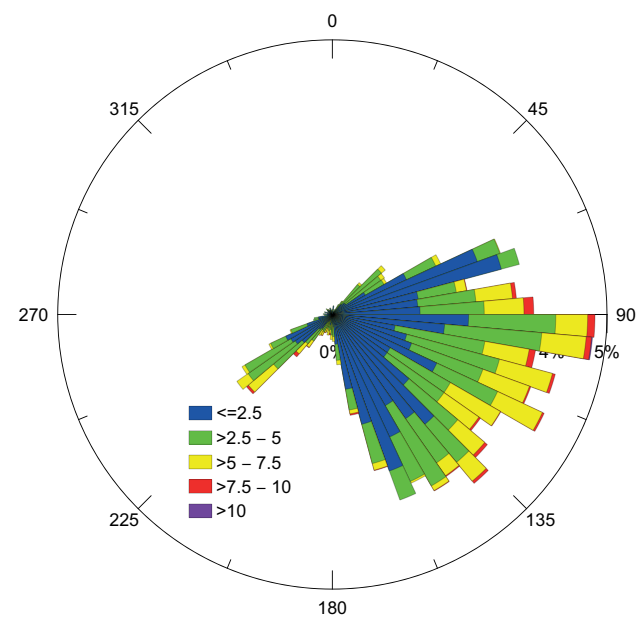

(c)

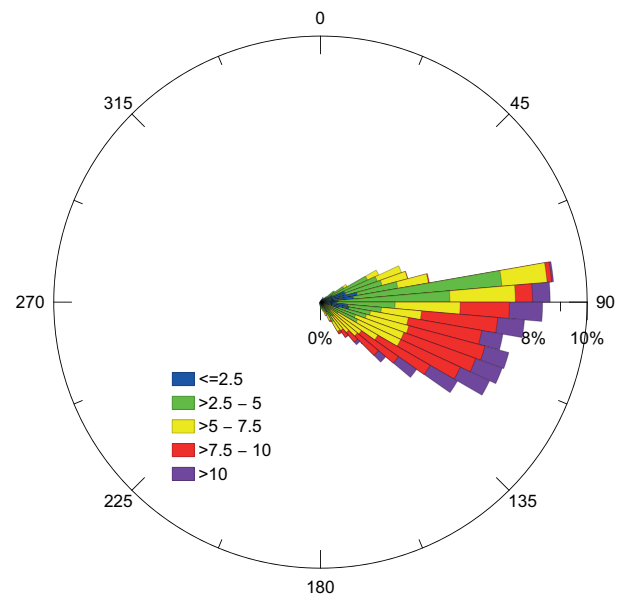

(b)

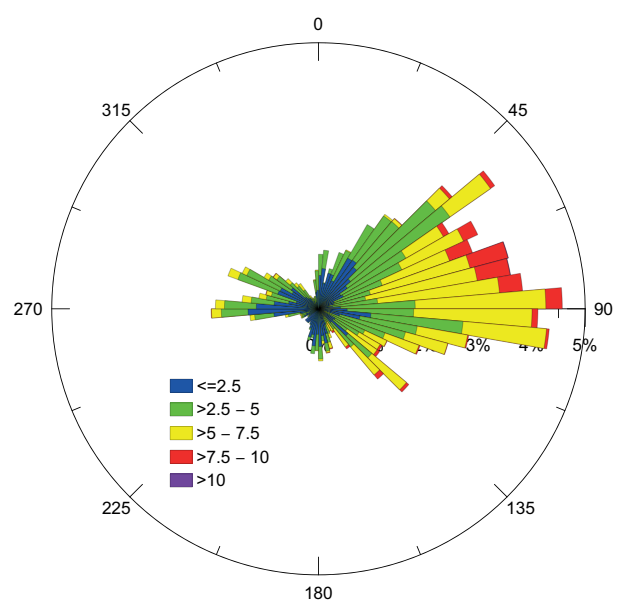

(d)

Figure 2. The preliminary wind atlas in the region of measurement at the height of $2 \mathrm{~m}$ for the years: (a) 2009; (b) 2011; (c) 2013; (d) 2020. The values are given in $\mathrm{m} \mathrm{s}^{-1}$. The east wind directions are typical for observation period during each field campaigns.

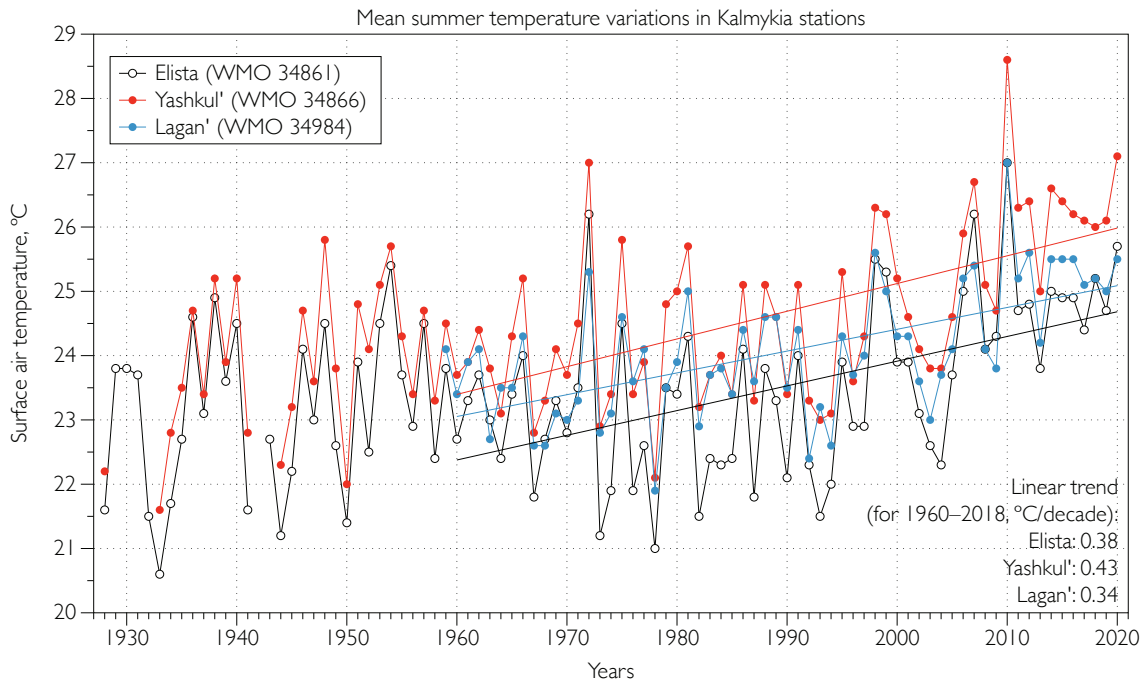

Figure 3. Variations of mean summer temperature of surface air in Kalmykia meteorological stations Lagan, Yashkul and Elista (data from [64,65]). 


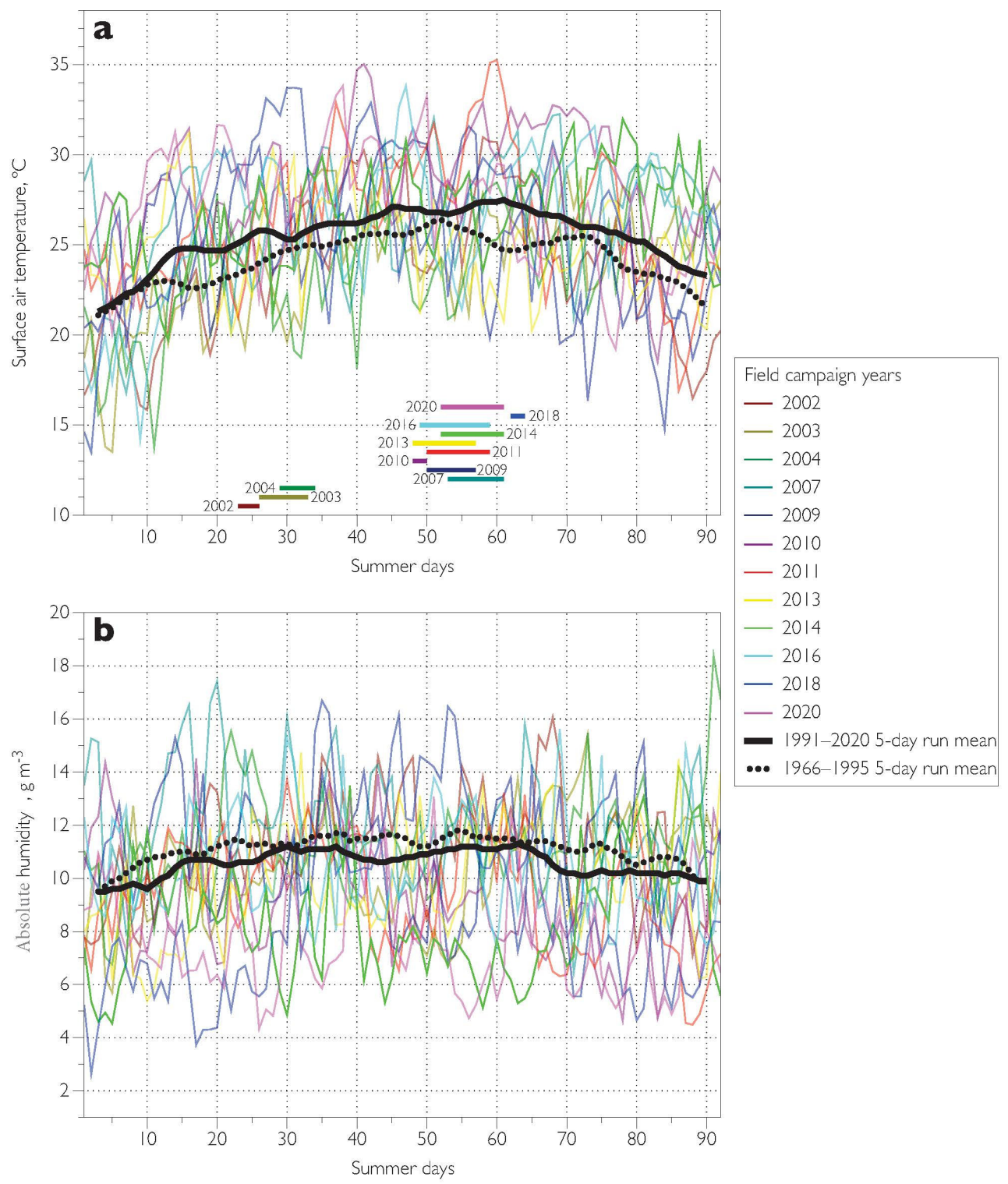

Figure 4. Daily means of summer surface air temperature (a) and absolute humidity (b) variations in the Yashkul meteorological station (by $[64,65]$ ) for each year of field campaign (colored curves). The black bold curves denote 5-day run average of climatic mean values for 1991-2020 (solid lines) and for 1966-1995 (dash lines). Colored horizontal lines at the lower part of the Figure 4a represent the durations of each field campaign.

Interannual variability of AOD (Figure 5) shows that periods of field campaigns-at least those that were conducted before 2012 - in general, were typical for this time of the year, except for the 2009 campaign that was characterized by decreased AOD values. It is of note, that high AOD values are typical for May-July for the analyzed region (Figure 6) with the absolute maximum AOD observed in the second half of June. The average AOD for the region is $0.25-0.3$, and the values over 0.95 quantile reach 0.5 . 


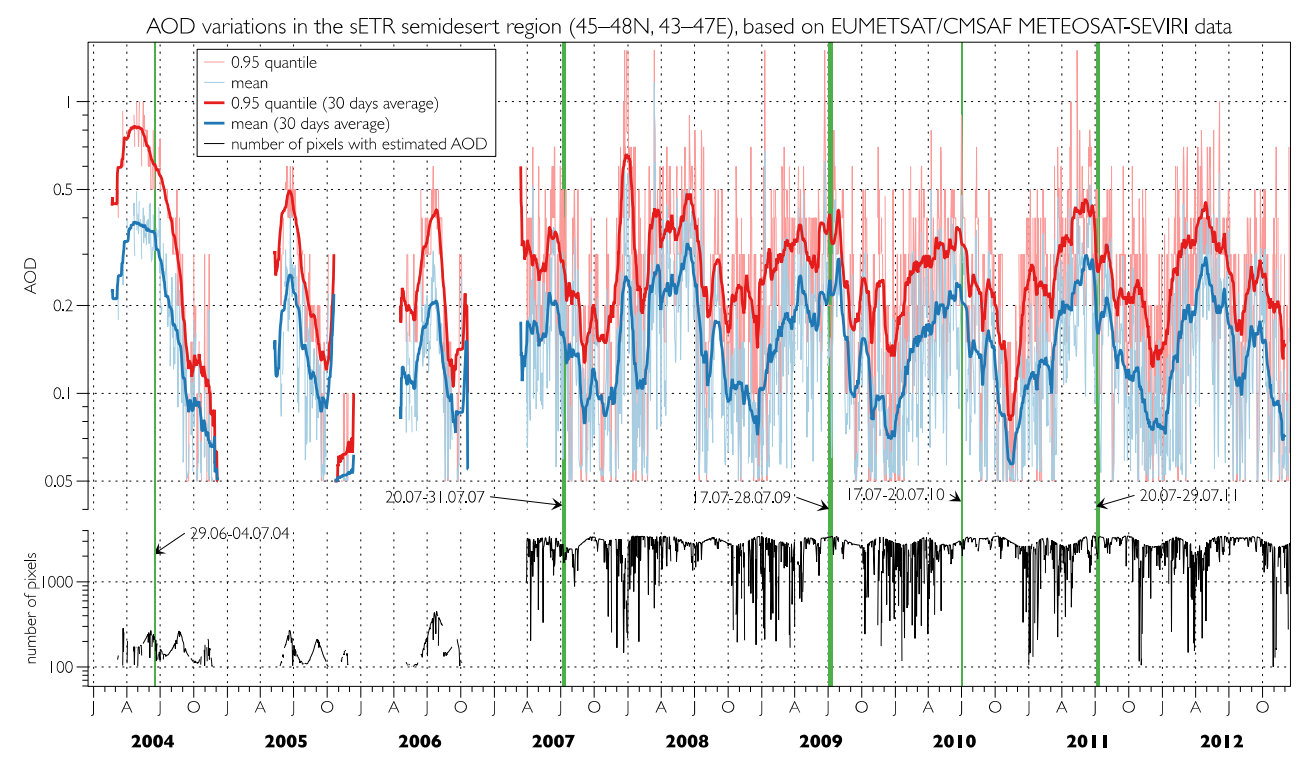

Figure 5. Daily AODs according to the data of the EUMETSAT-CMSAF product based on the SEVIRI instrument on the METEOSAT satellite [59] for the arid region of the southern ETR (45-48 $\mathrm{N}$, $43-47^{\circ} \mathrm{E}$ ). Thin lines show daily AODs (regional average (blue) and 0.95 quantile (red)), thick linesmoving average for 30 days. Values were defined only for the days for when region AODs was defined for at least 100 pixels. The black line shows the number of pixels involved into calculations (the 'jump' in 2007 is associated with the changing of the METEOSAT- 8 satellite with the new one, METEOSAT-9). Vertical green lines mark the months of field campaigns.

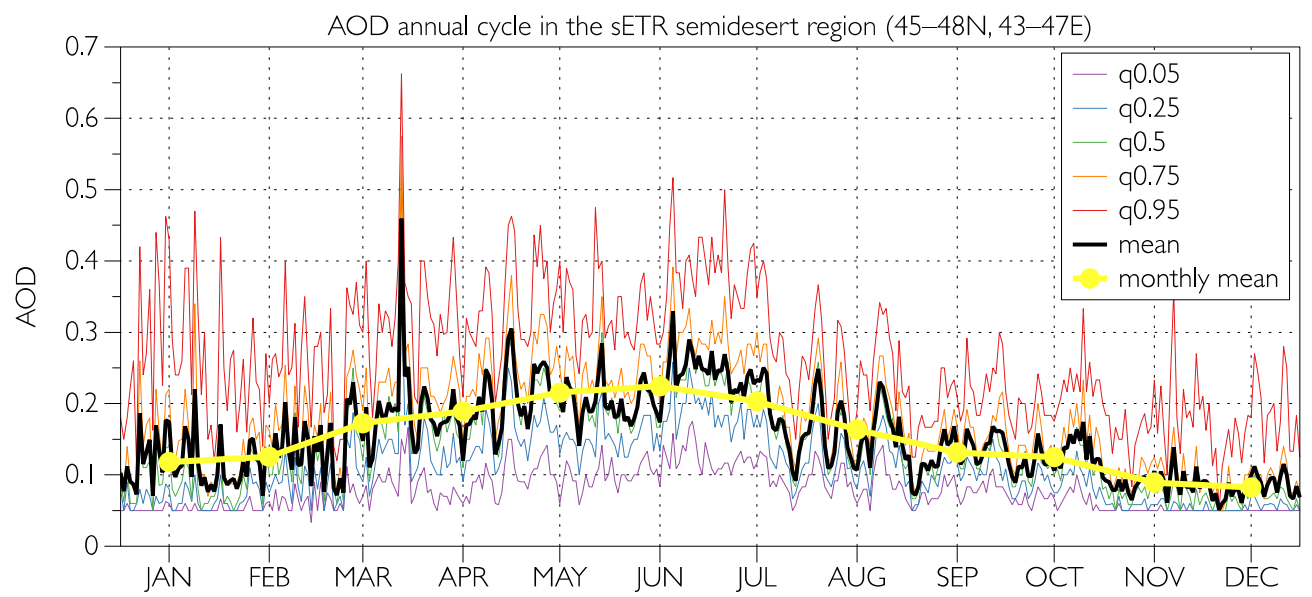

Figure 6. Annual variation of daily AODs according to the data of the EUMETSAT-CMSAF product based on the SEVIRI instrument on the METEOSAT-9 satellite [59] for the arid region of the southern ETR (45-48 N, 43-47 E) for the period 2007-2012. Different quantiles are shown with thin lines. The black thick line is the regional daily averaged AOD. The yellow line is the regional monthly averaged AOD.

\subsubsection{Dust Number Concentration}

The number (counting) concentration and size distribution of aerosol particles were measured in the daytime (usually from 09:00 to 19:00) at two levels: $0.5 \mathrm{~m}$ and $2.0 \mathrm{~m}$ (in 2002, 2003, 2004, 2007, 2010, 2011, 2013, 2014, 2016, 2018 and 2020) and $0.5 \mathrm{~m}$ and $1.5 \mathrm{~m}$ (2009) with Laser Aerosol Spectrometer (LAS-PC) (model 9814.290.000 designed and assembled at Karpov Physics and Chemistry Institute, which had certification) and a Royco Optical Particle Counter, Model 220 (Royco Instrument, Inc., Menlo Park, CA, USA). The 10-aerosol channels laser aerosol spectrometer LAS-PC indicated dispersed composition, number concentration; particle size (diameter) range $0.15-2 \mu \mathrm{m}$ at number concentrations 
up to 2.103 particles per $\mathrm{cm}^{3}$. The 10-channels optical-electric aerosol spectrometer OEAS05 measured dispersed composition, number concentration in the aerosol particle size (diameter) range $0.3-6.5 \mu \mathrm{m}$ at a number concentration of up to 103 particles per $\mathrm{cm}^{3}$. Based on the gravimetric method using filters installed at a certain particle size (cascade in 6-stage impactor), we can estimate the mass concentration of particles of such a size; and subsequently, after making a chemical analysis of the filter, evaluate aerosol composition of this size.

An aspiration sampler (air flow rate of $12 \mathrm{~m}^{3} \mathrm{~h}^{-1}$ ) with a set of filters APhA-KhA-20 was used for evaluating chemical composition and mass concentration of aerosols.

Determination of the disperse composition and number concentration of aerosol particles has been performed by laser spectroscopy. Determination of the mass concentration of particles has been received by the gravimetric method.

To determine the aerosol mass concentration, samples were deposited on analytical filters of the KhA-20 type at the height of 1.5-2.0 m from the underlying surface using an aspiration sampler with a sampling time of at least $12 \mathrm{~h}$ (day or night). The mass concentration was determined discretely by the weight method. This method include capturing aerosol on the filter from a certain volume of air, determining the filter weight gain and calculating the mass concentration value in $\mu \mathrm{gm}^{-3}$. (6-stage cascade impactor was used simultaneously with sampling for filters to determine the mass concentration of aerosol particles).

The measurement of meteorological parameters and turbulence parameters was carried out simultaneously with the determination of aerosol parameters.

A more detailed description of the instruments and the instrument's working mechanisms is given in the $[48,51]$.

The chemical composition of aerosols and soils was determined by the method of atomic emission spectrometry with inductively coupled plasma (ICP-AES).

\subsection{Dust Flux Computation}

The calculation of the vertical dust flux based upon the gradient method requires to measure and evaluate the dynamical parameters characterizing the structure of the surface boundary layer (the wind friction velocity, surface roughness length, Monin-Obukhov's length [66]) and the dust concentrations at two heights (instrumentation is described at Section 2.2.2).

Experimental data and theoretical estimates show that particle detachment from the underlying surface can be associated with turbulent stresses created by wind shear in the surface boundary layer-saltation mechanism. However, a large amount of fine particles exists in the ABL under weak wind conditions. Such particles can be lifted in the absence of saltation, when the wind force is insufficient to form strong shear turbulence over the underlying surface. The aerosol entrainment is related to the strong convection of the air over the sand layer during hot weather, where temperature drops in the thin surface air layer cause the dust resuspension-non-saltation mechanism. Detailed description of the physics of non-saltation emission processes is given in $[48,60]$. The emission occurs when the friction velocity reaches a corresponding for each mechanisms critical value.

The friction velocity was calculated according to the Monin-Obukhov theory [66] from the velocity gaps at different levels $(2 \mathrm{~m}$ and $10 \mathrm{~m}$ according to the values of the meteorological mast with sensors AANDERAA Instruments in all years except 2007 and 2018. In 2018 the upper level was located at a height of $5 \mathrm{~m}$. In 2007 simple logarithmic formula was used) and amounted on average to $0.05-0.5 \mathrm{~m} \mathrm{~s}^{-1}$. The wind friction velocity, surface roughness length, and Monin-Obukhov's length have been determined using the measured wind velocity and temperature profiles. Aerosol flux has been calculated using $[33,63]$, assuming neutral conditions and that the vertical transport of particles with a diameter $\leq 20 \mu \mathrm{m}$ is similar to that of momentum:

$$
F(P M)=u_{*} k\left(C_{l}-C_{h}\right) / \ln \left(z_{h} / z_{l}\right),
$$


where $k$ is the von Karman's constant $(k=0.4), u_{*}$-friction velocity and $C_{l}$ and $C_{h}$ are the dust mass concentrations measured in the surface boundary layer at a low $\left(z_{l}\right)$ and high $\left(z_{h}\right)$ altitudes (0.5 and 1.5 (or 2.0, it is dependent on the year of measurements) $\mathrm{m}$ ).

Heat fluxes were calculated, see, for example, [67] using:

$$
F_{\text {heat }}=-\left(u_{*}\right)^{3}\left(\theta \rho C_{p}\right) / k g L_{M O},
$$

where $k$ is the von Karman's constant $(k=0.4), L_{M O}-$ Monin-Obukhov's length, $g$ acceleration of gravity, $\theta$-air temperature, $\rho$-air density, and $C_{p}$-specific heat at constant pressure.

For the $\mathrm{PM}_{20}$ emission three mechanisms are considered as being responsible: direct aerodynamic entrainment [68], the combination of saltation and sandblasting, and nonsaltation emission [48]. These particles, especially fine mode of PM20, have a residence time in the troposphere long enough to be transported over great distances and to form the aerosol layers $[35,38,69,70]$. During their stay in the ABL, they can impact the Earth's climate [71-74] and human health [15,75-77]. The detailed description of the investigating methods for PSD's study in Kalmykia was given in [51].

\subsection{Trajectory Analysis}

The backward trajectories of air masses were calculated using the NOAA HYSPLIT model [78]. The evaluating of transport probability fields in the context of its long-term variability was through the technique explained in [79].

To study the transport probability the statistics of direct air particle trajectories was used. In [55], estimates of the probability of air transport from Kalmykia to the Moscow region from the surface layer of 0.1 and at an altitude of $1 \mathrm{~km}$ in 1986-2018 were calculated. In this work, the change in the probability of transport in recent decades are estimated.

\subsubsection{Forward Trajectory Modelling}

Five-day forward trajectories of air particles were calculated using the NOAA HYSPLIT_4 trajectory model [78] and the gridded (horizontal resolution $2.5^{\circ} \times 2.5^{\circ}, 17$ levels in height, time resolution $3 \mathrm{~h}$ ) meteorological achieve NCEP/NCAR Reanalysis [80,81] covering the period from 1949 to the present. The trajectories were calculated for 6 times (UTC 01:00, 07:00 and so on) of every day started from the ABL above unnamed point (45.3 N, 46.1 E; south of Kalmykia) simultaneously at three heights $H / 3,2 \times H / 3$ and $H$, where $\mathrm{H}$ is the mixed layer depth that is practically equal to ABL height.

\subsubsection{Air Transport Probability Reconstruction}

Probability of air transport was calculated for periods of 1991-2018, 1991-2004 and 2005-2018 using the methodic described in [55]. Then fields of change of air transport probabilities in 2005-2018 relative to 1991-2004 (i.e., for the last 15-30 years) were calculated. The fields of the probability and its change (spatial resolution of $2^{\circ} \times 2^{\circ}$ ) were drown using GIS-Softwate MeteoInfo [82].

\section{Results and Discussion}

\subsection{Mass Concentration and Aerosol Flux}

One of the most important parameters of aerosols is the mass concentration of aerosol particles, depending on various factors conditions (see Section 2.3). When studying the behavior of the characteristics of arid aerosols, the statistical factor of the reproducibility of the results under similar meteorological and other conditions is also of interest. Over the long-term observation period of field campaigns, series of variations in the values of the aerosol mass concentration were obtained.

Fine aerosol mass concentrations for the entire observation period are shown in the Figures 7 and 8 . 

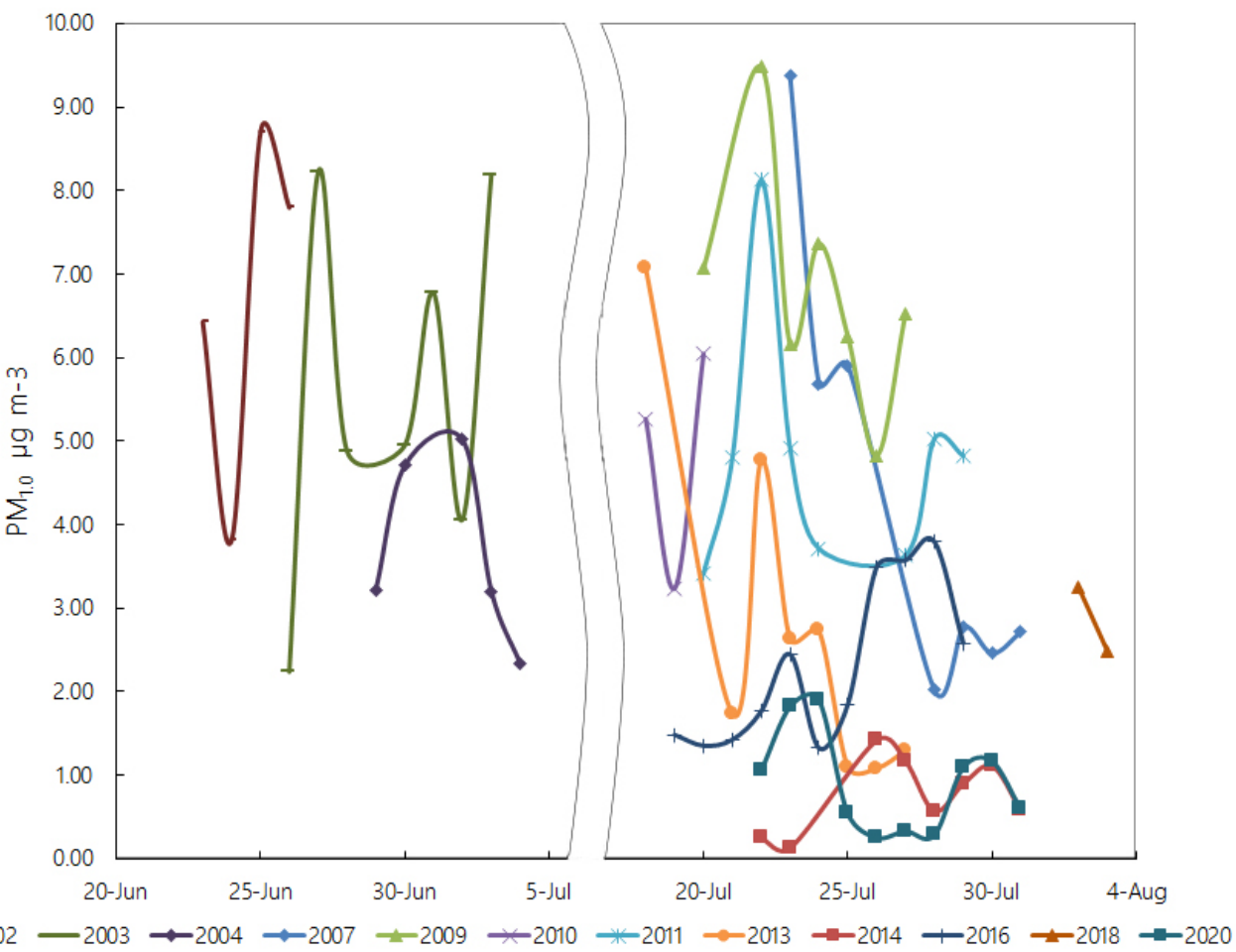

Figure 7. Daily mass concentration of $\mathrm{PM}_{1.0}$ (according to LAS data. The optical aerosol particle size range in our study is close to size range of $\mathrm{PM}_{1.0}$ ) for the entire observation period of 2002-2020.

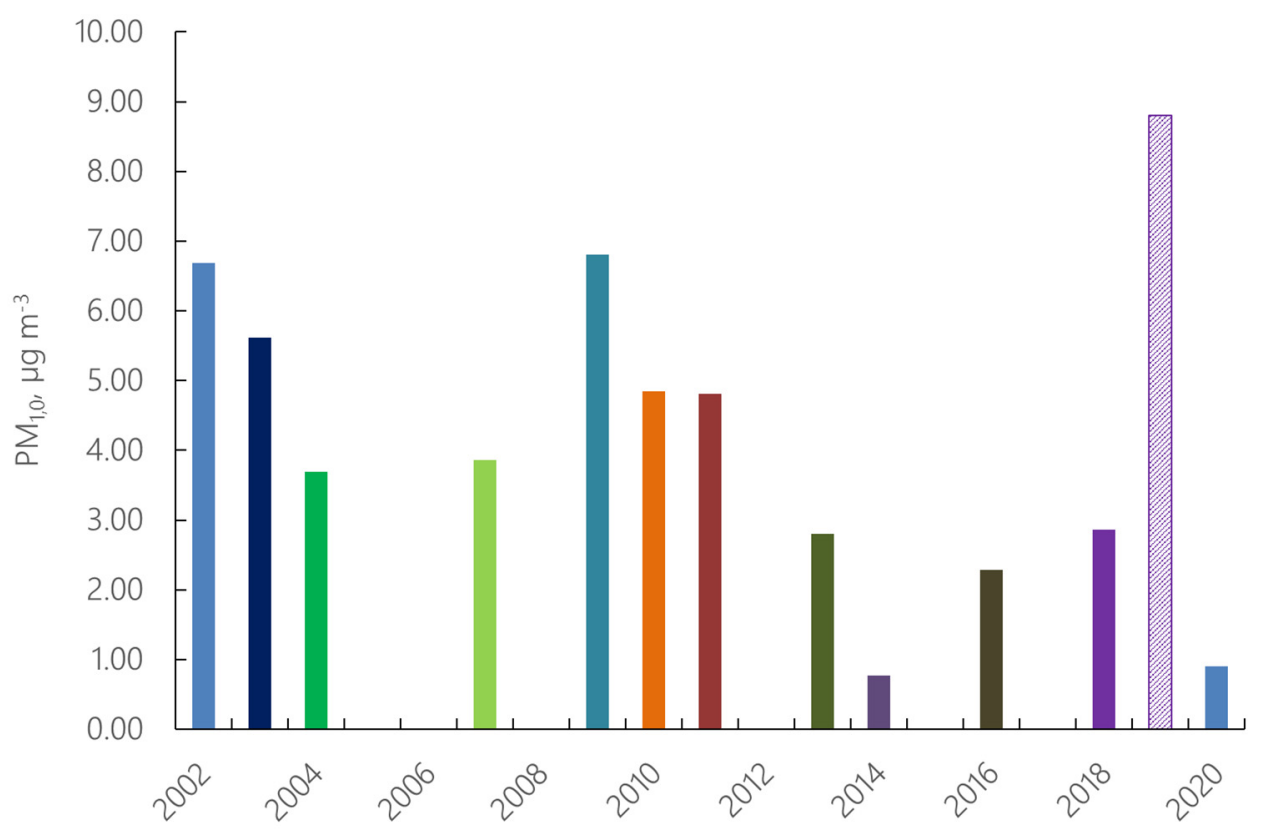

Figure 8. Annual changes in $\mathrm{PM}_{1.0}$ (according to LAS data) for years of 2002-2020 at a high altitude. A dust storm was recorded on 1 August 2018: the average value of the mass concentration in 2018 has shown with (hatching) and without (solid) taking into account 1 August 2018.

In 2009, 2013, the convective regime of emission prevailed, in 2011 the wind regime dominated. This is seen from the magnitude of fluxes and from the dependence of the aerosol mass concentration on the dynamic friction velocity in Figures 9 and 10. The variations in aerosol mass concentration due to variation in friction velocity indicate the mechanism of emission. The power dependence between these two characteristics 
represents the strong influence of wind to the entrainment process and, respectively, saltation mechanism of aerosol emission.
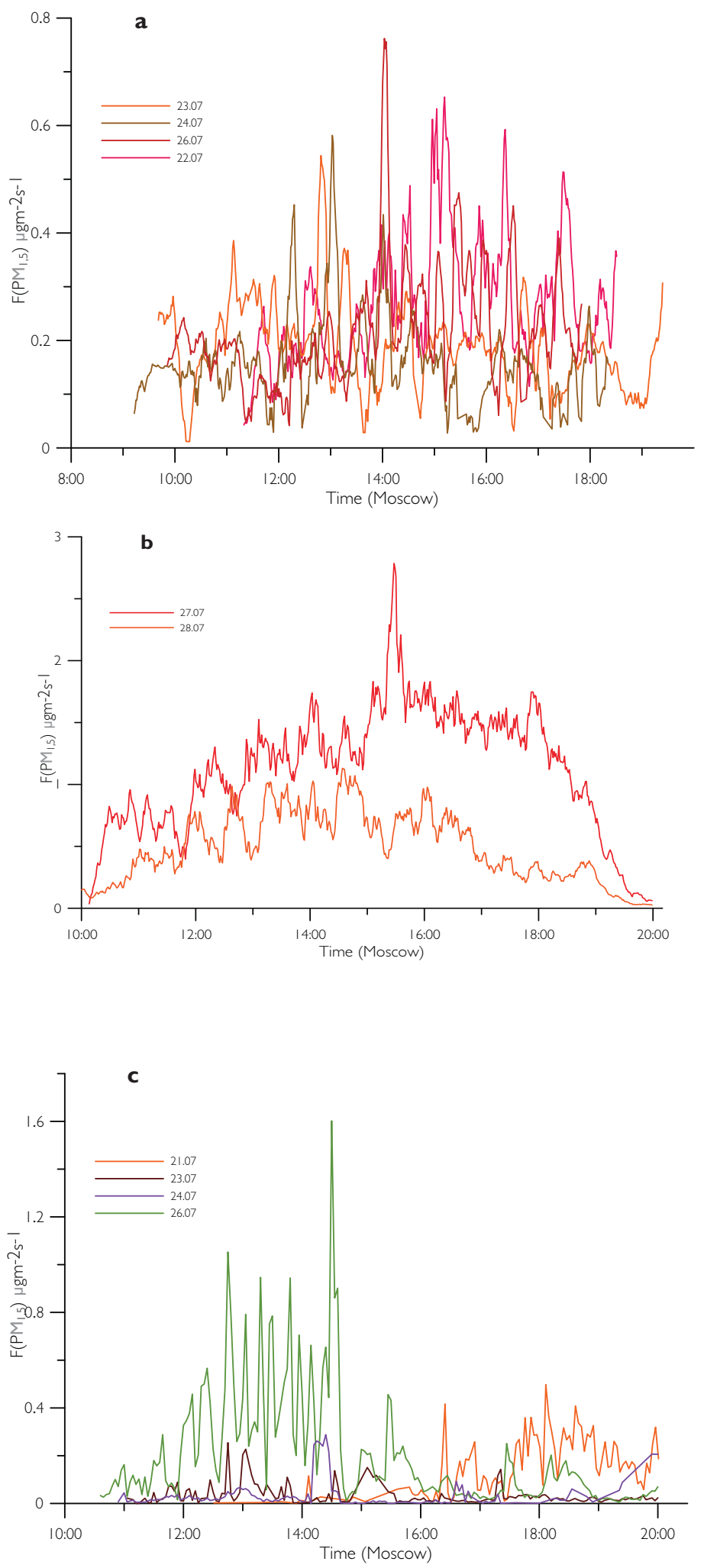

Figure 9. Aerosol flux ( $\left.\mathrm{PM}_{1.5}\right)$ : (a) for 22, 23, 25 and 26 July 2009; (b) for 27 and 28 July 2011; (c) for 21, 23, 24 and 26 July 2013. 


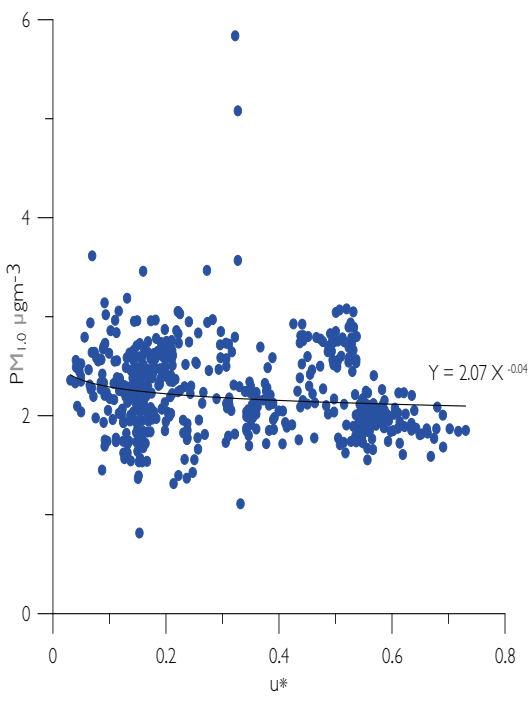

(a)

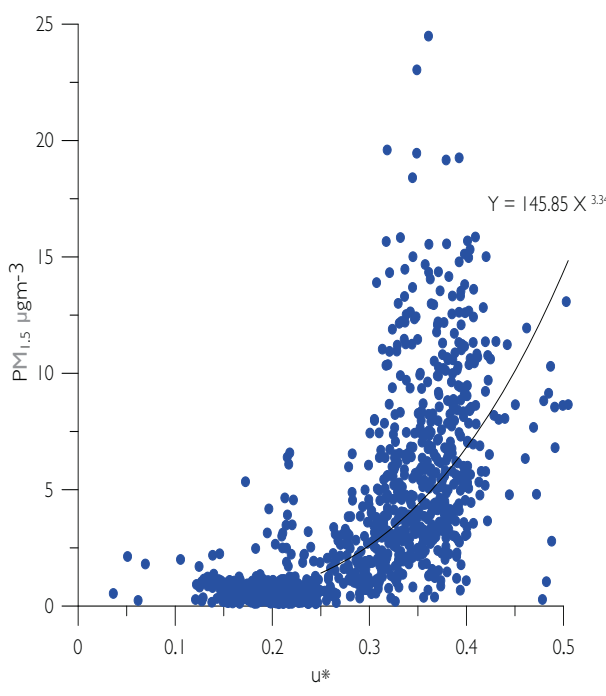

(b)

Figure 10. Correlation diagrams between the aerosol mass concentration and the dynamic friction velocity $\left(\mathrm{u}^{*}\right)$ : (a) convective mechanism, $P M_{1.0}$ for 24 July 2009; (b) saltation mechanism, PM 1.5 for 28 July 2011.

The combination of regimes was noted in all years. Nevertheless, wind entrainment of particles, saltation mechanism prevailed for 2010 and 2011, and convectional entrainment of particles, non-saltation mechanism prevailed for 2009, 2013 and 2014. The characteristic feature of the non-saltation regime is its connection with heat fluxes. Consequently, the dependence of the aerosol flux on sensible heat flux is almost linear for the non-saltation regime. The heat flux depends on saltation, but, in general, the wind velocity is weakly related to the heat flux, so the aerosol flux mostly grows with the increase of sensible heat flux. Figure 11 represent the variance of the aerosol flux depending on the sensible heat flux.

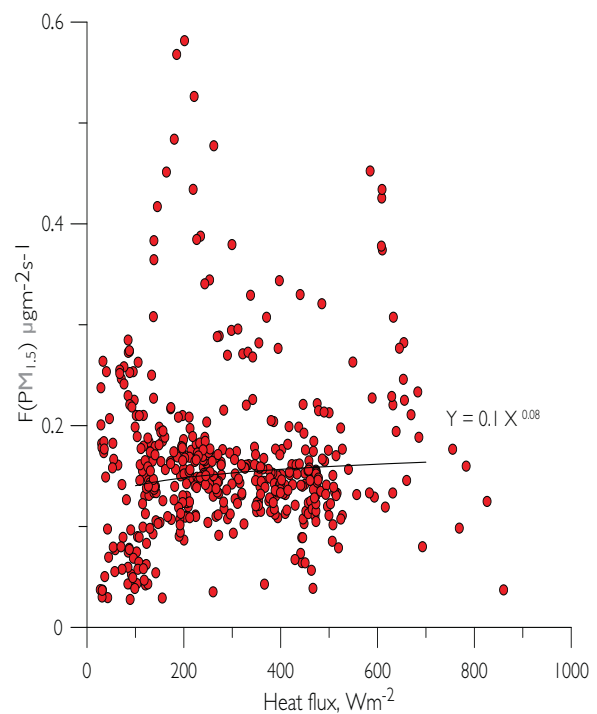

(a)

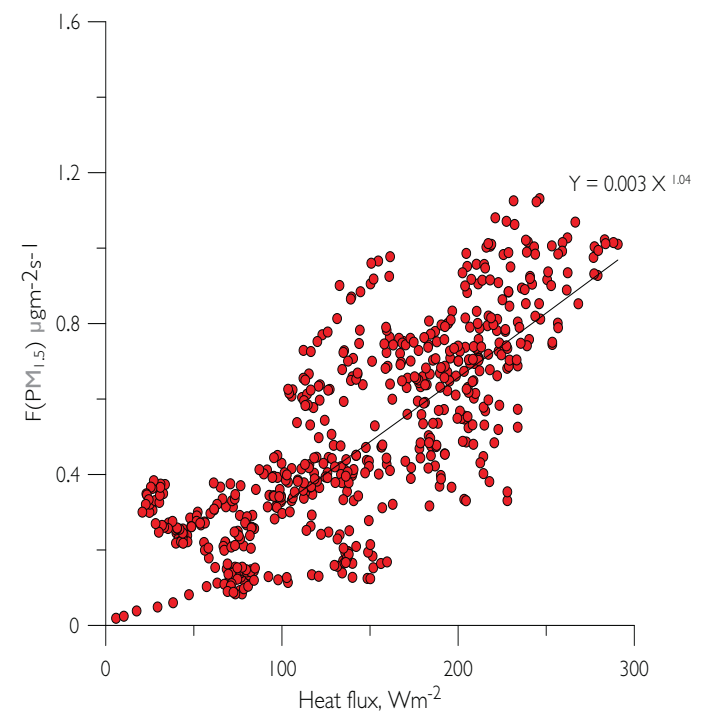

(b)

Figure 11. Correlation diagrams between the aerosol flux $\left(P M_{1.5}\right)$ and the sensible heat flux $\left(F_{\text {heat }}\right)$. Daytime: 10:00-20:00: (a) Convectional entrainment of particles, non-saltation mechanism prevails for 24 July 2009; (b) Wind entrainment of particles, saltation mechanism prevails for 28 July 2011. 


\subsection{Aerosol Composition}

Apart from mass concentrations and fluxes, aerosol composition is also of great importance. Temporal distribution of chemical elements in surface aerosols of Kalmykia for the observation period 2007-2016 is ambiguous. The highest values of the mass content of almost all elements of the global distribution are typical for 2009 and 2011 (Figure 12). It is noticed that during the observation period 2007-2016 the mass content of these elements is decreased in the surface aerosols of Kalmykia. The highest values of the mass content of elements of regional distribution were observed and shown here by example of 2007 and 2013 (Figure 13). For Ti, Mn, Fe, Zn, Co and Y insignificant year-to-year fluctuations in the mass content in surface aerosols are characteristic.

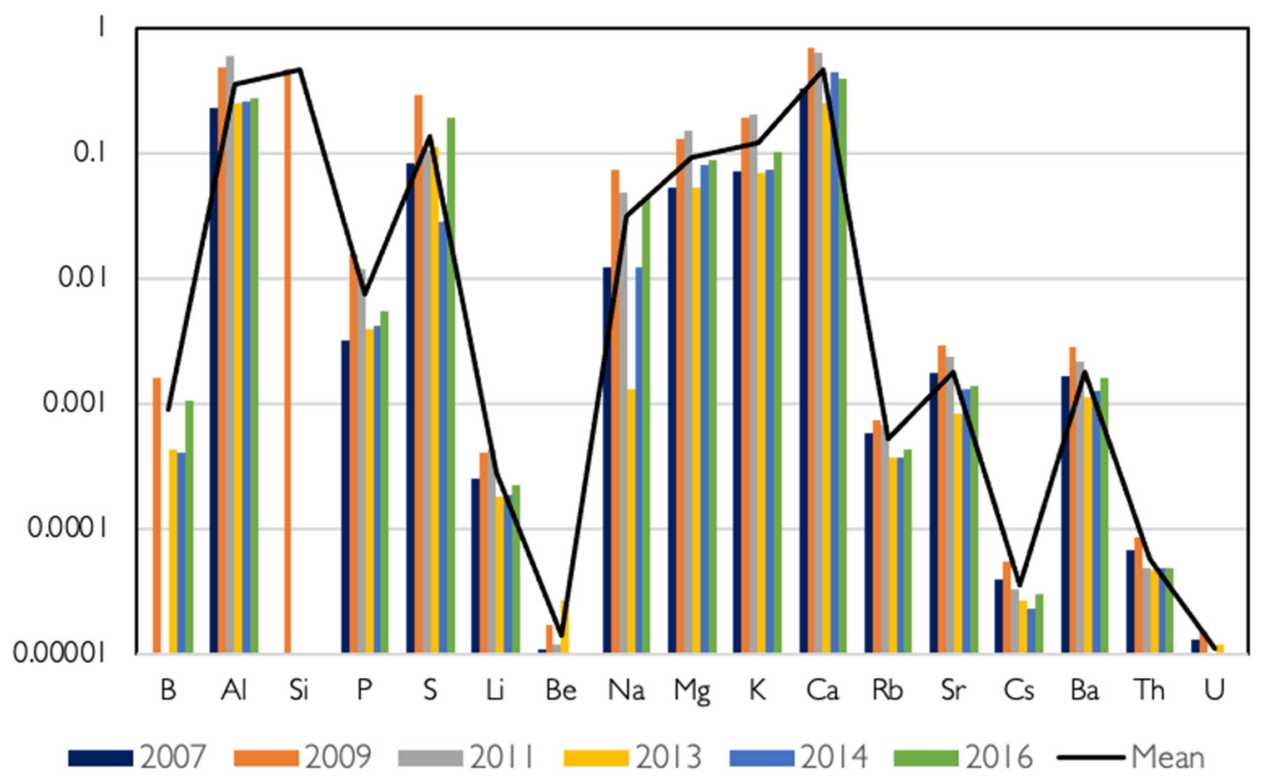

Figure 12. Percentage of mass content of chemical elements of global distribution in the aerosol particles over semi-arid lands of Kalmykia in different years of 2007-2016. Black line is the averaged percentage of the indicated element for all years. We used the data on the elemental composition of aerosol in Kalmykia, published, in particular, in Table 4 [61].

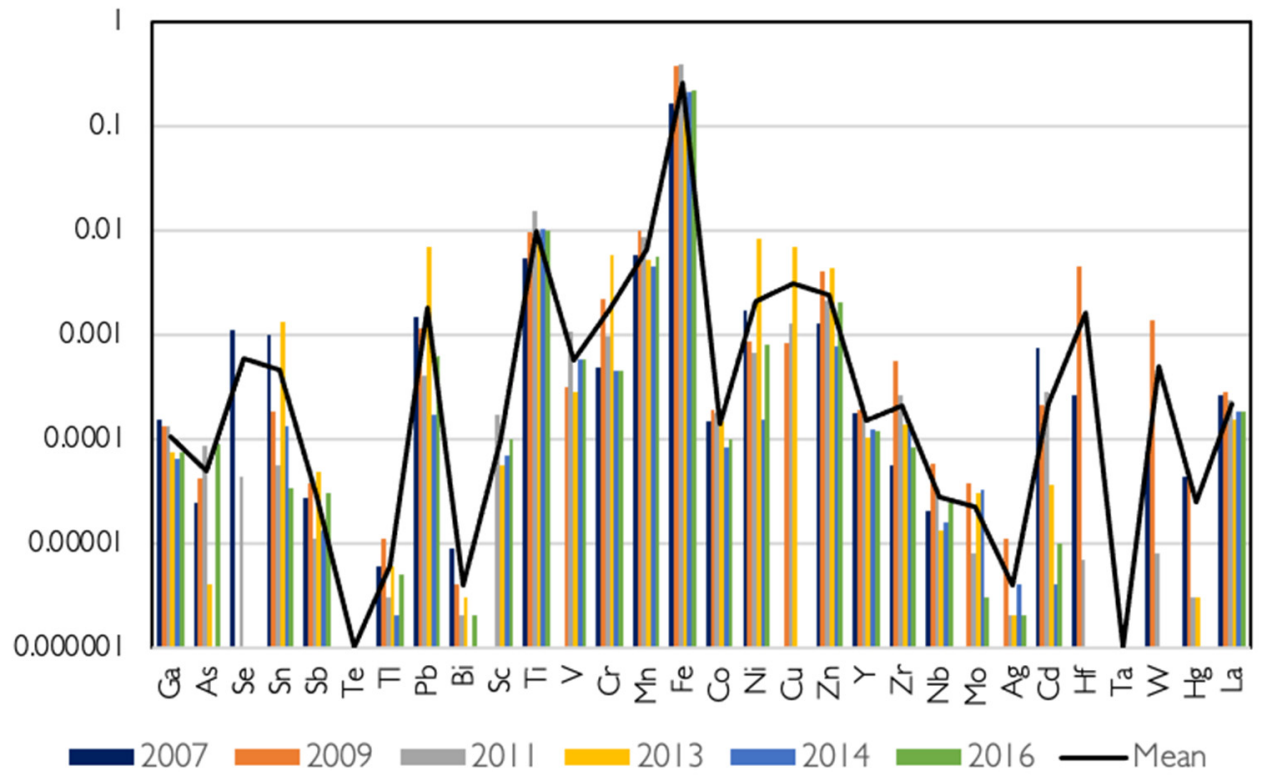

Figure 13. The same as at Figure 12 but for regional and local distribution. 
The mass content in the surface arid aerosol of most of the elements of global distribution, which have a mineral nature $(\mathrm{Al}, \mathrm{Si}, \mathrm{Na}, \mathrm{Mg}, \mathrm{Ca})$, strongly depends on meteorological conditions. This content increases in windy conditions, during dust storms due to saltation emission of particles from the underlying surface [61]. The saltation is the main factor that determines the revealed interannual variability of the concentration of these elements in the surface aerosol during the period under consideration.

Phosphorus and sulfur, with its mixed (anthropogenic-lithogenic) nature, are classified as elements of global importance due to their wide distribution and constantly increased concentration. The interannual variability of their concentration in aerosol particles of Kalmykia can be associated with the particularity of local anthropogenic sources, such as activities of enterprises for the development of oil-and-gas and oil-and-gas-condensate fields. In addition, the increased sulfur content in the deserted areas of Kalmykia may be associated with the entrainment of particles from the surface of the Solonchaks, typical soil cover of the deserted regions of the Caspian Lowland and Central Asia.

Most of the considered elements of regional and local significance are of a mixed nature: either predominantly lithogenic or predominantly anthropogenic. More detailed

For example, local soils are enriched with arsenic and heavy metals such as $\mathrm{Hg}, \mathrm{Co}$, $\mathrm{Cr}, \mathrm{Cu}, \mathrm{Zn}, \mathrm{Mo}$ and $\mathrm{Cd}$ [61]. These trace elements enter the atmosphere due to the emission from the underlying surface. However, oil-and-gas enterprises and motor transport also contribute to the total content of these elements in aerosols of the observation region. The main source of elements such as $\mathrm{Sn}, \mathrm{Pb}, \mathrm{Ni}, \mathrm{Hf}, \mathrm{W}$ is anthropogenic activity and regional transport from adjacent territories. Therefore, the interannual variability of the concentration of elements of regional and local significance is strongly dependent on the specifics of local and regional anthropogenic sources.

The groups of elements according to their variability from 2007 to 2016 were described in [61]. Chemical composition of soils of major landscapes in the Chernozemel'skii district of Kalmykia were given in Table 3 in [61]. The highlighted elements are characterized by significant values of the percentage mass content and linked to industrial activities. Table 5 in [61] show the coefficient of aerosol concentration and the coefficient of local aerosol concentration in soil and surface atmospheric particles in background landscapes of Kalmykia related to the enrichment factor by mass of the element in aerosol (aerosol). The calculated aerosol-concentration coefficients $\left(\mathrm{CC}_{\mathrm{a}}=\right.$ aerosol/earth crust $)$ and local aerosol-concentration coefficients $\left(\mathrm{CC}_{\mathrm{as}}=\mathrm{aerosol} / \mathrm{soil}\right)$ are the degree of enrichment of soil landscapes and surface aerosols in semiarid regions of observed area. Accumulation of elements in surface aerosol particles classified according to the natural and naturalanthropogenic landscapes of Kalmykia is presented in Table 6 in [61].

The elemental composition of aerosols is closest to the composition of fine and medium dust (particles $1-10 \mu \mathrm{m}$ in size (diameter)) of sandy soil (correlation coefficient $\mathrm{R}=0.73$ ), differing from the composition of soils of dry steppe $(R=0.69)$ and Solonchaks $(R=0.50)$.

Having studied the chemical composition of sandy soils and aerosol particles in the surface layer of arid zones of Kalmykia, we have revealed that the predominant fraction in the soil is the fraction of fine sand $(86.6 \%)$, significantly exceeding the percentage of fractions of silt, medium and coarse sand. The chemical composition of the sand sample is aluminum-silicon. The amount of silicon oxide exceeds $80 \%$, aluminum-10\%. The amount of iron oxide is only $2.5 \%$, calcium $-2.2 \%$. Alkaline earth elements are $-1.5 \%$ calcium oxide and $1.8 \%$ magnesium oxide. The predominant fraction for the main microelements of aerosol particles is the fraction of fine sand $(1-5 \mu \mathrm{m})$, the fraction of sludge by percentage is several times less, and large particles $(5-10 \mu \mathrm{m})$ are the smallest values, with the exception of lead. The results of elemental and mineralogical analysis of soil and aerosol particles confirmed the identity of the chemical composition of the highly dispersed fraction of soil and aerosol. 


\subsection{Aerosol Transport}

The surface air layer, as well as the ABL, over the arid region of Kalmykia is characterized in the warm season by an increased aerosol load [79]; therefore, it is of interest to study the probability of long-range transport of air particles (potentially polluted with dust) from the ABL over the arid territories to remoted regions. All other things being equal, this probability reflects the potential transport of atmospheric pollutants (including dust aerosol) from the arid region.

Fine particles suspended in air can be transported over long paths and form the aerosol layers which greatly contributed to the radiation and energy balance. Characteristic aerosol trajectories of different regions requires thorough analysis.

The 3-day backward trajectories of air masses, calculated using the NOAA HYSPLIT model [78] for the observation period in Kalmykia from 21 July to 31 July 2020, are shown in the Figure 14.

To study mean climatic characteristics in the context of long-term variability, the transport probability fields were reconstructed using array of about 300,000 modeled forward trajectories. The fields characterize the potential aerosol transport in the lower troposphere from the observation site to Russian regions and to neighbor countries.

Only those cells are shown that crossed with at least 150 trajectories. Seasonal average probability of air particle transport may illustrate the probability of transport in different seasons of the year, as well as the seasonal areas of the transport. Air transport from the boundary layer over the deserted areas of Kalmykia in all seasons is most likely in the western, southwestern and, slightly less probably, in the southeastern directions from the areas. Southwestern regions of Russia (Stavropol, Rostov, Astrakhan, Krasnodar, Volgograd oblasts and the Republic of Crimea) are most susceptible to potential aerosol transport from the arid region of Kalmykia. Figure 15 reflects the changes in potential dust transport probability in the modern period (last 15-25 years). Over the period in all seasons, the transport probability to the central regions of the European part of Russia (Tatarstan and Samara and Volgograd Oblasts and others), and in the summer also to the Rostov Oblast and Crimea, has increased.

Variations in the average seasonal probability of air particles transport from the ABL over the deserted lands of Kalmykia to Moscow are given at Figure 16. It is seen the probability is decreased or stable in all seasons excluding winter when the probability is doubled for the last 25-30 years. The linear trend values (and their statistical significance) from Figure 16 are given in Table 3. In winter, spring and summer over the past 50-60 years there has been a decrease (statistically significant only in summer and spring) of the average seasonal air transport probability; in autumn, there are no statistically significant trends.

Until 1990 there was a decrease in the probability in all seasons, the largest and statistically significant one in summer. After 1990 there was a statistically significant positive trend in winter; in other seasons, there is no significant transport trend in the lower troposphere. 


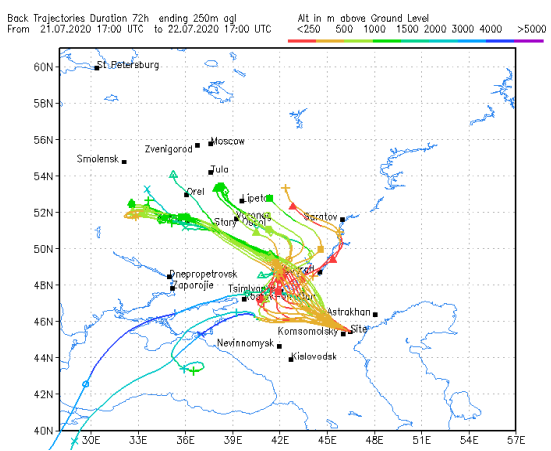

(a)

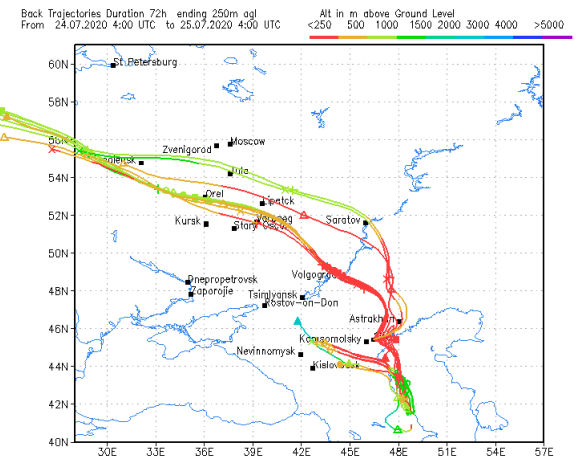

(d)

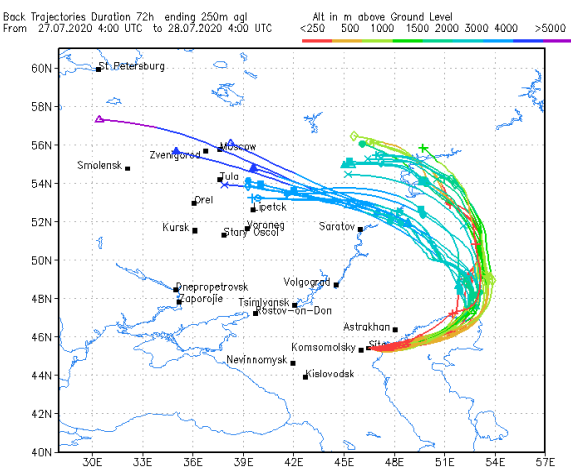

(g)

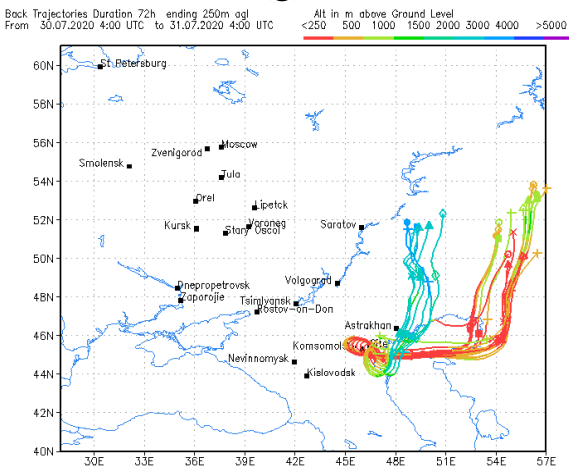

(j)

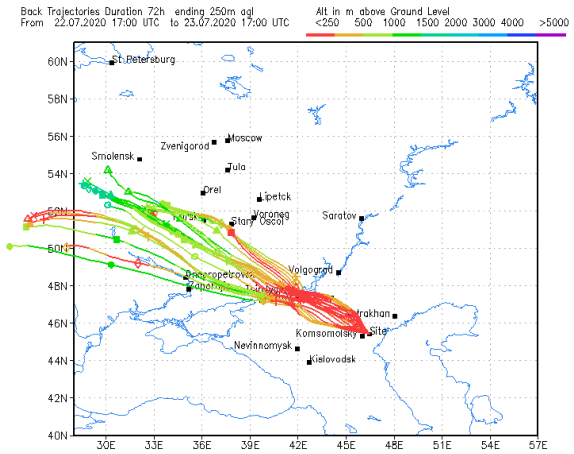

(b)

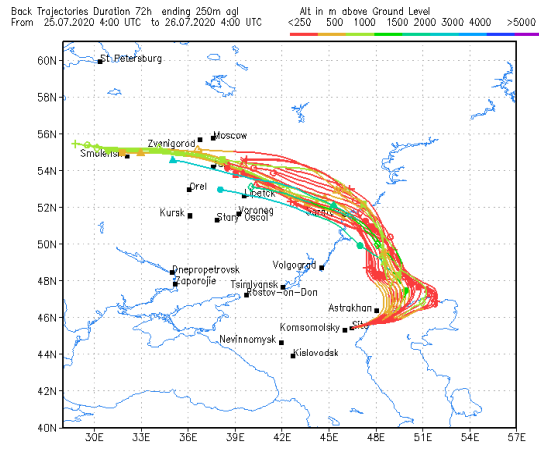

(e)

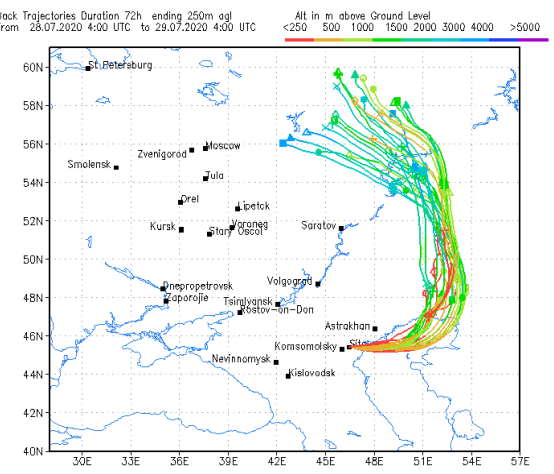

(h)

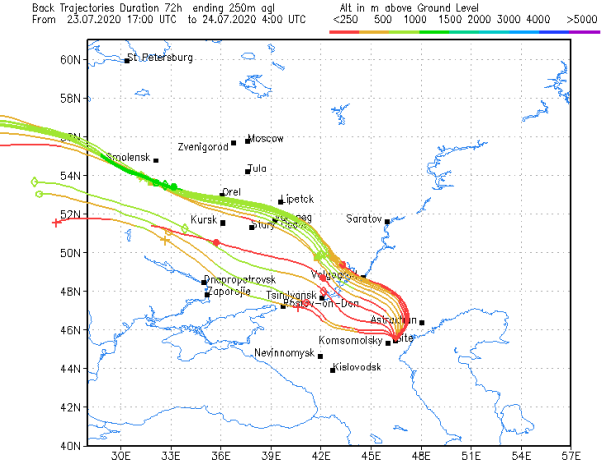

(c)

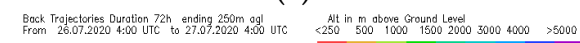

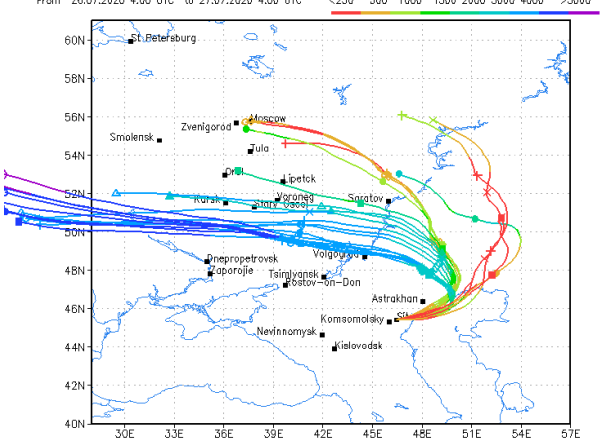

(f)

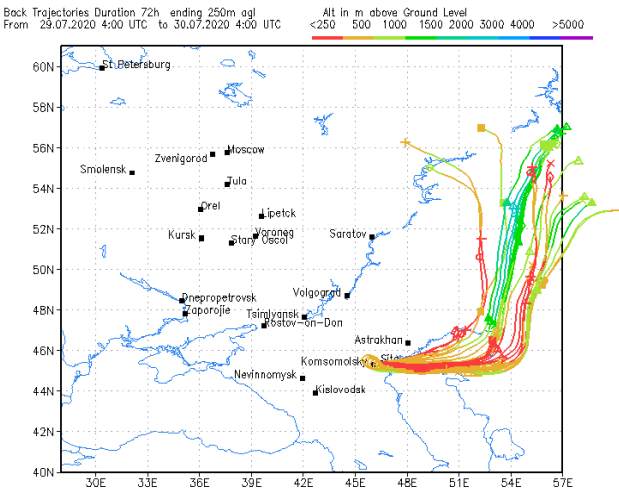

(i)

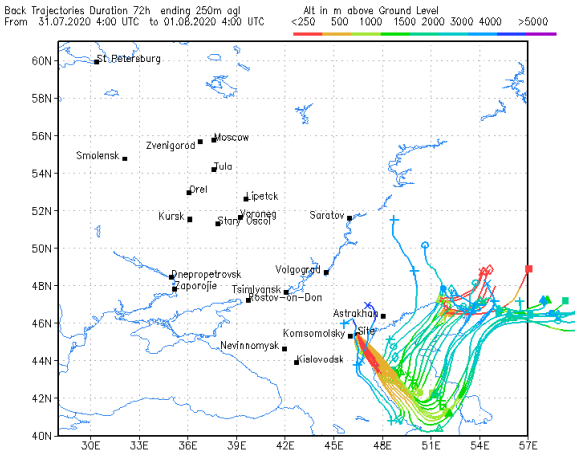

(k)

Figure 14. Three-day backward trajectories of air particles calculated using the NOAA HYSPLIT 4 model for the observation period in Kalmykia from 21 July (a) to 31 July (k), 2020. Trajectory drawings are listed sequentially (a-k). 

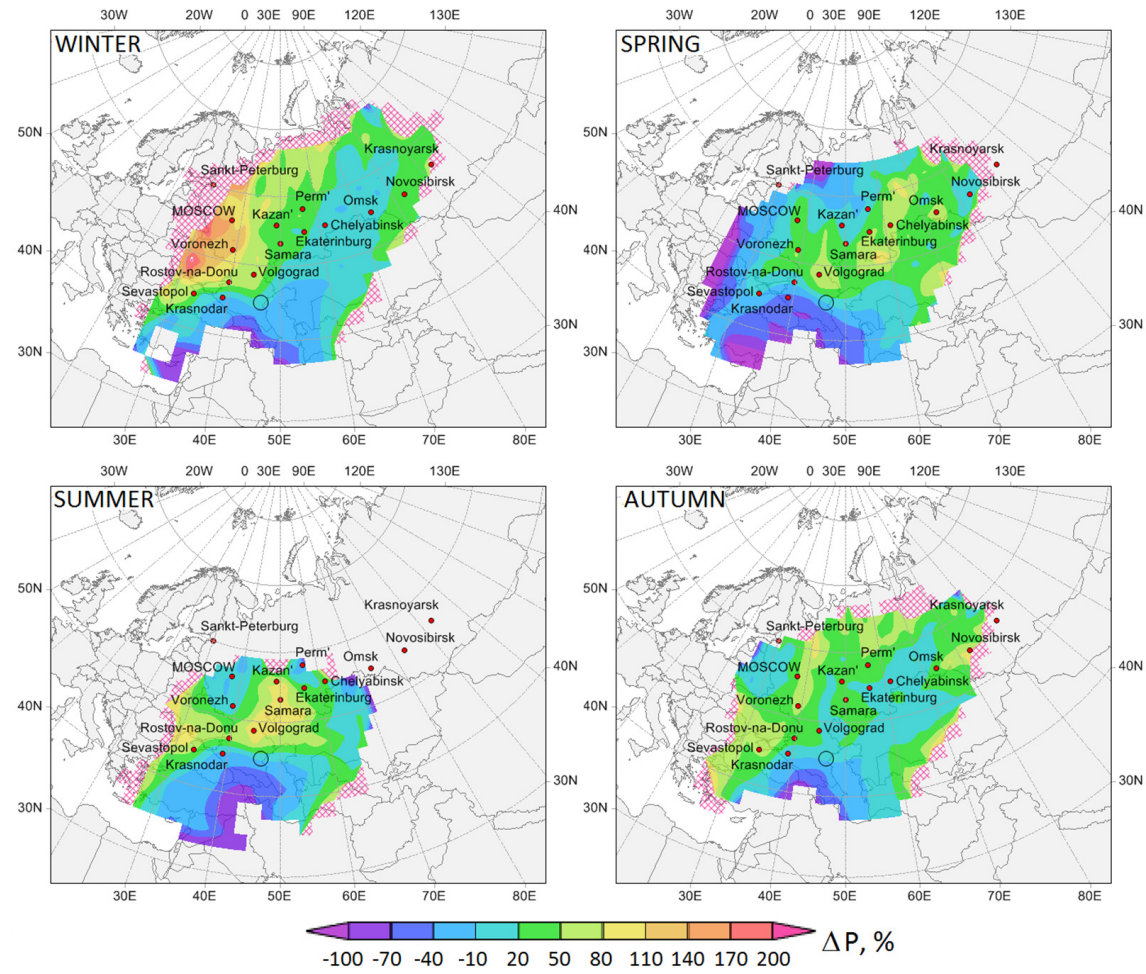

Figure 15. Change in the average seasonal probability of air particles transport, $\Delta \mathrm{P}[\%]$, from the boundary layer over the deserted lands of Kalmykia in 2005-2018 compared with 1991-2004. The magenta shaded areas indicate (here and after) the new transport areas that arose only in the later period.
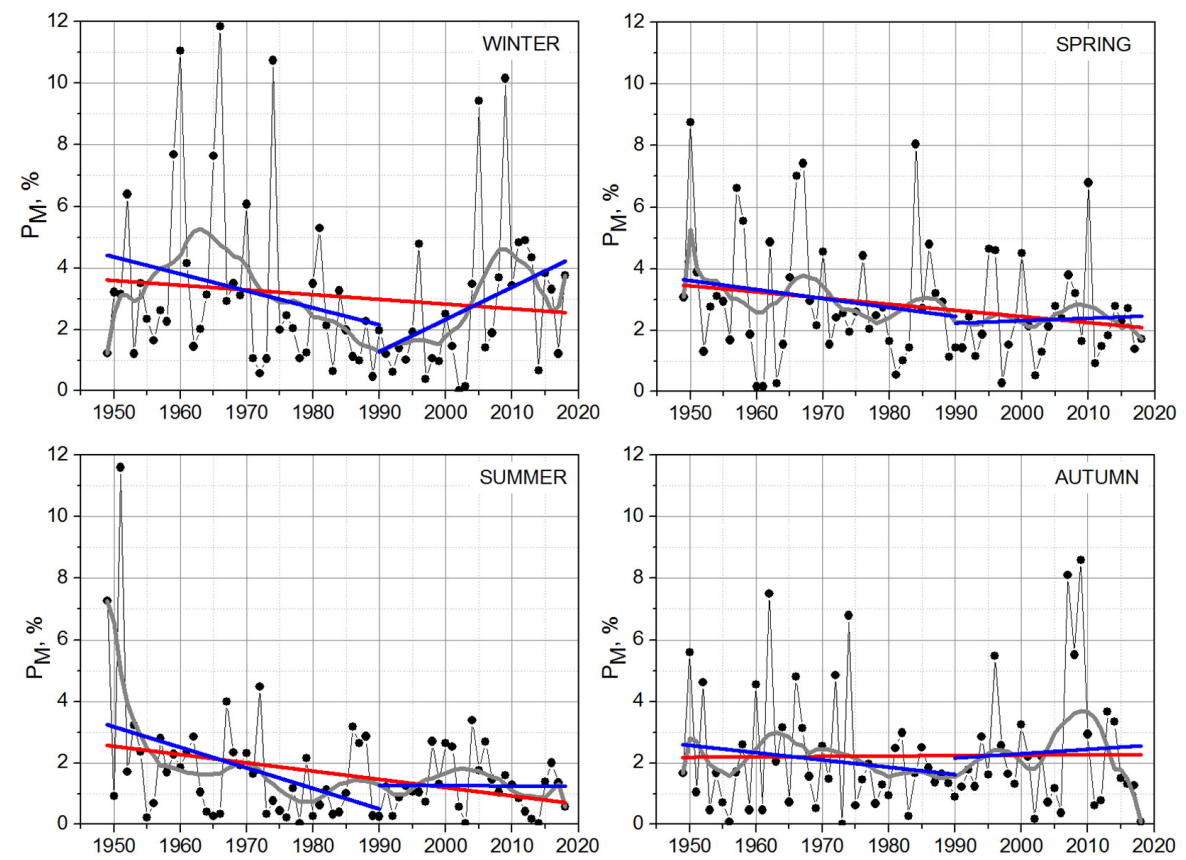

Figure 16. Variations in the average seasonal probability of transport, Pm [\%], of air particles from the boundary layer over the deserted territory of Kalmykia to the Moscow region in 1949-2018. (black line). The gray line is the 10-year moving average. The red line is a linear annual trend in 1949-2018. Blue lines are linear annual trends in 1949-1989 and in 1990-2018. 
Table 3. Linear annual trends, $\mathrm{k}$ [\%/(10 years)], and their significance, $p$, for the average seasonal probability of air particles transport from the deserted lands of Kalmykia to the Moscow region in 1949-2018, 1949-1989 and 1990-2018.

\begin{tabular}{ccccccc}
\hline & \multicolumn{2}{c}{ 1949-2018 } & \multicolumn{2}{c}{ 1949-1989 } & \multicolumn{2}{c}{$\mathbf{1 9 9 0 - 2 0 1 8}$} \\
\hline Season & $\mathrm{k}$ & $p$ & $\mathrm{k}$ & $p$ & $\mathrm{k}$ & $\mathrm{c}$ \\
winter & -0.15 & 0.34 & -0.55 & 0.13 & 1.1 & 0.05 \\
spring & -0.19 & 0.07 & -0.29 & 0.29 & 0 & 0.96 \\
summer & -0.26 & 0.008 & -0.66 & 0.01 & 0.1 & 0.8 \\
autumn & 0.01 & 0.91 & -0.24 & 0.31 & 0.1 & 0.77 \\
\hline
\end{tabular}

\section{Conclusions}

As it mentioned in [35], the recent achievements in dust emission research are substantial, but to improve quantitative emission modelling and prediction we should focus on accurate determination of the key parameters which affect emission. Some fundamental aspects of the physics of emission are not completely understood. Consequently, dustemission schemes contain parameters which must be determined empirically. However, there is a lack of high-quality observational data sets for the thorough validations of dustemission schemes; therefore, large uncertainties may exist in scheme parameters and new field experiments need to be carried.

In spite of their importance for the prediction and simulation of the entrainment, transport and deposition of mineral dust, "in-situ" measurements of the dust emission flux and PSD under realistic wind conditions remain rare, especially for the former territory of the USSR.

In this paper the spatial and temporal trends of aerosol emissions, its chemical composition and transport characteristics for arid and semi-arid areas in the Caspian Lowland Desert in the south of Russia (Kalmykia) were performed based on field sample collections, satellite images and direct measurements in the site of investigation.

Long-term series of data on the mass and number concentration, dispersed and elemental composition of aerosol in the surface layer of the atmosphere of deserted areas of the steppe zone of Kalmykia were obtained. The auxiliary data of meteorological parameters (air temperature and humidity, wind velocity and direction, pressure, etc.) were provided.

The characteristic values of the mass and number concentration of aerosol particles in the semi-desert zones of Kalmykia in the summer period are determined for the observation period 2002-2020. In particular, the mass concentration in different years of observation ranged from several tens to several hundred $\mu \mathrm{g} \mathrm{m}^{-3}$. It was confirmed that for these field campaigns the aerosol emission arose from two different mechanisms: saltation (associated with turbulent stresses created by wind shear in the surface boundary layer) and nonsaltation (related to the strong convection of the air over the sand layer during hot weather, where temperature drops in the thin surface air layer cause the dust entrainment). The latter mechanism was predominant in Kalmykia in summer period. It is noted from the data received that a large number of fine particles exists in the ABL under weak wind conditions.

An identification of possible aerosol sources of natural and anthropogenic origin as well as trajectory analysis of air mass transport from and to studied arid region were performed. An increased content of anthropogenic elements ( $\mathrm{S}, \mathrm{Sn}, \mathrm{Pb}, \mathrm{Bi}, \mathrm{Mo}, \mathrm{Ag}, \mathrm{Cd}, \mathrm{Hg}$, etc.), which is characteristic of all observation points in the south of the European part of Russia, was found. The elements were revealed mainly in submicron and coarse aerosol and enter the studied regions with air masses from industrial and/or highly populated territories due to long-range air transport.

Analysis of 5-day forward trajectories of air particles for 1949-2018 showed that air transport from the boundary layer over the deserted areas of Kalmykia in all seasons is most likely in the western, southwestern and, slightly less probably, in the southeastern directions from the regions. Southwestern regions of Russia are most probable recipients of the dust emitted from deserts of Kalmykia. At the same time, over the past three decades, 
compared to three decades before the start of modern global warming, the probability of the air transport to these regions of the Russia has decreased, while for a number of central regions of the European territory of Russia (ETR) and some regions of the Asian territory of Russia (ATR) has increased. Thus, the dust emitted from the deserted lands of Kalmykia in recent decades has become an increasingly significant climatic and ecological factor both for most of the ETR and for a number of western Siberia regions of Russia.

A preliminary analysis of submicron aerosol fluxes does not clearly reveal an increase or decrease trend; however, there is a relationship with general synoptic factors of a general annual scale. Despite the trends towards an increase in temperature and humidity, there are no stable emission trends towards an enhance; but the situation may worsen: for example, the hot dry summer of 2020 led to an intensification of dust emissions and the formation of a severe dust storm event in autumn 2020 (that reached even the Atlantic) [83].

Author Contributions: Conceptualization, O.G.C.; methodology, O.G.C., A.V.C., K.A.S. and N.V.V.; software, O.G.C., A.V.C., N.V.V., K.A.S. and L.O.M.; validation, O.G.C., A.V.C., N.V.V. and K.A.S.; formal analysis, O.G.C., A.V.C., N.V.V., K.A.S., F.A.K., D.P.G. and L.O.M.; investigation, O.G.C., A.V.C., N.V.V., K.A.S., F.A.K., D.P.G., L.O.M., M.S.A. and T.M.K.; resources, O.G.C.; data curation, O.G.C., N.V.V., A.V.C. and K.A.S.; writing—original draft preparation, N.V.V.; writing-review and editing, O.G.C., A.V.C., K.A.S., D.P.G. and M.S.A.; visualization, O.G.C., A.V.C., N.V.V., K.A.S., F.A.K., D.P.G., L.O.M. and M.S.A.; supervision, O.G.C.; project administration, O.G.C.; funding acquisition, O.G.C. All authors have read and agreed to the published version of the manuscript.

Funding: Section 1: Section 2 (except Section 2.2.2), Section 3.1, Section 3.3, Section 4 of this research was funded by the Russian Science Foundation, project no. 20-17-00214 and Sections 2.2.2 and 3.2 of this research was funded by the Russian Foundation for Basic Research, project no. 19-05-50110.

Data Availability Statement: Data sets for this research are publicly available at the EUDAT Collaborative Data Infrastructure website http:/ / doi.org/10.23728/b2share.a43d99a2f4f64c6c8c09a8 93ddd415fa (accessed on 27 July 2021). Meteorological station data are available at http:/ / meteo. ru/english/climate/cl_data.php (accessed on 27 July 2021) [52]. CMSAF satellite data on AOD are available at doi:10.5676/EUM_SAF_CM/MSG_AOD/V001.

Acknowledgments: The authors are grateful to G.S. Golitsyn for his interest in the work and constructive comments, and for his continued support of this study. The authors thank M.A. Iordanskii, Y.V. Zhulanov, Y.A. Obvintscev, V.A. Lebedev, A.A. Khapaev, S.A. Kosyan and B.A. Khartskhaev (Komsomol'skiy, Kalmykia) for their help in organizing and carrying out field measurements.

Conflicts of Interest: The authors declare no conflict of interest. The funders had no role in the design of the study; in the collection, analyses or interpretation of data; in the writing of the manuscript or in the decision to publish the results.

\section{References}

1. Andreae, M.O. Climate effects of changing atmospheric aerosol levels. World Surv. Climatol. 1995, 16, 347-398. [CrossRef]

2. Textor, C.; Schulz, M.; Guibert, S.; Kinne, S.; Balkanski, Y.; Bauer, S.; Berntsen, T.; Berglen, T.; Boucher, O.; Chin, M.; et al. Analysis and quantification of the diversities of aerosol life cycles within AeroCom. Atmos. Chem. Phys. 2006, 6, 1777-1813. [CrossRef]

3. Zender, C.S.; Miller, R.L.L.; Tegen, I. Quantifying mineral dust mass budgets: Terminology, constraints, and current estimates. Eos Trans. Am. Geophys. Union 2011, 85, 509-512. [CrossRef]

4. Schepanski, K.; Heinold, B.; Tegen, I. Harmattan, Saharan heat flow, and West African monsoon circulation: Modulations on the Saharan dust outflow towards the North Atlantic. Atmos. Chem. Phys. 2017, 17, 10223-10243. [CrossRef]

5. Lu, H. An Integrated Wind Erosion Modelling System with Emphasis on Dust Emission and Transport. Ph.D. Thesis, University of New South Wales, Sydney, Australia, 1999.

6. Shao, Y.; Ishizuka, M.; Mikami, M.; Leys, J.F. Parameterization of size-resolved dust emission and validation with measurements. J. Geophys. Res. Atmos. 2011, 116, D08203. [CrossRef]

7. Ezhova, E.; Ylivinkka, I.; Kuusk, J.; Komsaare, K.; Vana, M.; Krasnova, A.; Noe, S.; Arshinov, M.; Belan, B.; Park, S.-B.; et al. Direct effect of aerosols on solar radiation and gross primary production in boreal and hemiboreal forests. Atmos. Chem. Phys. 2018, 18, 17863-17881. [CrossRef]

8. Wang, X.; Huang, J.; Zhang, R.; Chen, B.; Bi, J. Surface measurements of aerosol properties over northwest China during ARM China 2008 deployment. J. Geophys. Res. 2010, 115, D00K27. [CrossRef]

9. Wang, X.; Wu, J.; Chen, M.; Xu, X.T.; Wang, Z.H.; Wang, B.; Wang, C.Z.; Piao, S.L.; Lin, W.L.; Miao, G.F.; et al. Field evidences for the positive effects of aerosols on tree growth. Glob. Chang. Biol. 2018, 24, 4983-4992. [CrossRef] 
10. Mercado, L.M.; Bellouin, N.; Sitch, S.; Boucher, O.; Huntingford, C.; Wild, M.; Cox, P.M. Impact of changes in diffuse radiation on the global land carbon sink. Nature 2009, 458, 1014-1017. [CrossRef]

11. Schepanski-Homscheidt, M.; Oumbe, A.; Benedetti, A. Aerosols for concentrating solar electricity production forecasts: Requirement quantification and ECMWF/MACC aerosol forecast assessment. Bull. Am. Meteorol. Soc. 2013, 94, 903-914. [CrossRef]

12. Zhang, L.Y.; Wu, J. Main progress in research on reduced light rain in China during recent decades. Torrential Rain Disasters 2014, 33, 202-207. [CrossRef]

13. Sokolik, I.N.; Toon, O.B. Direct radiative forcing by anthropogenic airborne mineral aerosols. Nature 1996, 381, 681-683. [CrossRef]

14. Querol, X.; Tobías, A.; Pérez, N.; Karanasiou, A.; Amato, F.; Stafoggia, M.; Pérez García-Pando, C.; Ginoux, P.; Forastiere, F.; Gumy, S.; et al. Monitoring the impact of desert dust outbreaks for air quality for health studies. Environ. Int. 2019, $130,104867$. [CrossRef] [PubMed]

15. Du, Y.; Xu, X.; Chu, M.; Guo, Y.; Wang, J. Air particulate matter and cardiovascular disease: The epidemiological, biomedical and clinical evidence. J. Thorac. Dis. 2016, 8, E8. [CrossRef]

16. Sokolik, I.N.; Winker, D.M.; Bergametti, G.; Gillette, D.A.; Carmichael, G.; Kaufman, Y.J.; Gomes, L.; Schuetz, L.; Penner, J.E. Introduction to special section: Outstanding problems in quantifying the radiative impacts of mineral dust. J. Geophys. Res. Space Phys. 2001, 106, 18015-18027. [CrossRef]

17. Peng, J. Tentative discussion on the impact of aerosol on cloud and precipitation over Shanghai and its surrounding areas. Torrential Rain Disasters 2015, 34, 324-334. [CrossRef]

18. Bagnold, R.A. The Physics of Blown Sands and Desert Dunes, 1st ed.; Chapman \& Hall Ltd.: New Fetter Lane, London, UK, $1973 ; 265 p$.

19. Marinou, E.; Amiridis, V.; Binietoglou, I.; Tsikerdekis, A.; Solomos, S.; Proestakis, E.; Konsta, D.; Papagiannopoulos, N.; Tsekeri, A.; Vlastou, G.; et al. Three-dimensional evolution of Saharan dust transport towards Europe based on a 9-year EARLINET-optimized CALIPSO dataset. Atmos. Chem. Phys. 2017, 17, 5893-5919. [CrossRef]

20. Proestakis, E.; Amiridis, V.; Marinou, E.; Georgoulias, A.K.; Solomos, S.; Kazadzis, S.; Chimot, J.; Che, H.; Alexandri, G.; Binietoglou, I.; et al. Nine-year spatial and temporal evolution of desert dust aerosols over South and East Asia as revealed by CALIOP. Atmos. Chem. Phys. 2018, 18, 1337-1362. [CrossRef]

21. Kaufman, Y.J.; Koren, I.; Remer, L.A.; Tanré, D.; Ginoux, P.; Fan, S. Dust transport and deposition observed from the TerraModerate Resolution Imaging Spectroradiometer (MODIS) spacecraft over the Atlantic Ocean. J. Geophys. Res. Atmos. 2005, 110, 1-16. [CrossRef]

22. Liu, D.; Wang, Z.; Liu, Z.; Winker, D.; Trepte, C. A height resolved global view of dust aerosols from the first year CALIPSO lidar measurements. J. Geophys. Res. Atmos. 2008, 113, D16214. [CrossRef]

23. Peyridieu, S.; Chédin, A.; Capelle, V.; Tsamalis, C.; Pierangelo, C.; Armante, R.; Crevoisier, C.; Crépeau, L.; Siméon, M.; Ducos, F.; et al. Characterisation of dust aerosols in the infrared from IASI and comparison with PARASOL, MODIS, MISR, CALIOP, and AERONET observations. Atmos. Chem. Phys. 2013, 13, 6065-6082. [CrossRef]

24. Rashki, A.; Kaskaoutis, D.G.; Francois, P.; Kosmopoulos, P.G.; Legrand, M. Dust-storm dynamics over Sistan region, Iran: Seasonality, transport characteristics and affected areas. Aeol. Res. 2015, 16, 35-48. [CrossRef]

25. Gkikas, A.; Hatzianastassiou, N.; Mihalopoulos, N.; Katsoulis, V.; Kazadzis, S.; Pey, J.; Querol, X.; Torres, O. The regime of intense desert dust episodes in the Mediterranean based on contemporary satellite observations and ground measurements. Atmos. Chem. Phys. 2013, 13, 12135-12154. [CrossRef]

26. Gkikas, A.; Basart, S.; Hatzianastassiou, N.; Marinou, E.; Amiridis, V.; Kazadzis, S.; Pey, J.; Querol, X.; Jorba, O.; Gassó, S.; et al. Mediterranean intense desert dust outbreaks and their vertical structure based on remote sensing data. Atmos. Chem. Phys. 2016, 16, 8609-8642. [CrossRef]

27. Gillette, D.A. Fine particle emissions due to wind erosion. Trans. Am. Soc. Agric. Eng. 1977, 20, 890-897. [CrossRef]

28. Gillette, D.A.; Walker, T.R. Characteristics of airborne particles produced by wind erosion of sandy soil, high plains of west Texas. Soil Sci. 1977, 123, 97-110. [CrossRef]

29. Nickling, W.G.; Gillies, J.A. Dust emission and transport in Mali, West Africa. Sedimentology 1993, 40, 859-868. [CrossRef]

30. Gillette, D.A.; Passi, R. Modeling dust emission caused by wind erosion. J. Geophys. Res. 1988, 93, 14233-14242. [CrossRef]

31. Marticorena, B.; Bergametti, G. Modeling the atmospheric dust cycle: 1. Design of a soil-derived dust emission scheme. J. Geophys. Res. 1995, 100, 16415-16430. [CrossRef]

32. Shao, Y.P.; Raupach, M.R.; Leys, J.F. A model for predicting aeolian sand drift and dust entrainment on scales from paddock to region. Soil Res. 1996, 34, 309-342. [CrossRef]

33. Gillette, D.A.; Fryrear, D.W.; Gill, T.E.; Ley, T.; Cahill, T.A.; Gearhart, E.A. Relation of vertical flux of particles smaller than $10 \mu \mathrm{m}$ to total aeolian horizontal mass flux at Owens Lake. J. Geophys. Res. Atmos. 1997, 102, 26009-26015. [CrossRef]

34. Shao, Y. A model for mineral dust emission. J. Geophys. Res. 2001, 106, 20239-20254. [CrossRef]

35. Shao, Y. Physics and Modelling of Wind Erosion, 2nd ed.; Springer Science \& Business Media; University of Cologne: Cologne, Germany, 2008; Volume 37, 452p.

36. Klose, M.; Shao, Y.; Li, X.; Zhang, H.; Ishizuka, M.; Mikami, M.; Leys, J.F. Further development of a parameterization for convective turbulent dust emission and evaluation based on field observations. J. Geophys. Res. Atmos. 2014, 119, 10441-10457. [CrossRef] 
37. Greeley, R.; Iversen, J.D. Wind as a Geological Process: On Earth, Mars, Venus and Titan (No. 4); CUP Archive: Cambridge, UK, 1987; 333p.

38. Zheng, X. Mechanics of Wind-Blown sand Movements; Springer Science \& Business Media: Berlin/Heidelberg, Germany, 2009; 309p.

39. Shao, Y.; Zhang, J.; Ishizuka, M.; Mikami, M.; Leys, J.; Huang, N. Dependency of particle size distribution at dust emission on friction velocity and atmospheric boundary-layer stability. Atmos. Chem. Phys. 2020, 20, 12939-12953. [CrossRef]

40. Gillette, D.A. Production of dust that may be carried great distances. Geol. Soc. Am. 1981, 186, 11-26. [CrossRef]

41. Shao, Y.; Raupach, M.R.; Findlater, P.A. Effect of saltation bombardment on the entrainment of dust by wind. J. Geophys. Res. Atmos. 1993, 98, 12719-12726. [CrossRef]

42. Sow, M.; Alfaro, S.C.; Rajot, J.L.; Marticorena, B. Size resolved dust emission fluxes measured in Niger during 3 dust storms of the AMMA experiment. Atmos. Chem. Phys. 2009, 9, 3881-3891. [CrossRef]

43. Khalfallah, B.; Bouet, C.; Labiadh, M.; Alfaro, S.; Bergametti, G.; Marticorena, B.; Lafon, S.; Chevaillier, S.; Féron, A.; Hease, P.; et al. Influence of atmospheric stability on the size distribution of the vertical dust flux measured in eroding conditions over a flat bare sandy field. J. Geophys. Res. Atmos. 2020, 125, e2019JD031185. [CrossRef]

44. Rosenberg, P.D.; Parker, D.J.; Ryder, C.L.; Marsham, J.H.; Garcia-Carreras, L.; Dorsey, J.R.; Briiks, I.M.; Dean, A.R.; Crosier, J.; McQuaid, J.B.; et al. Quantifying particle size and turbulent scale dependence of dust flux in the Sahara using aircraft measurements. J. Geophys. Res. Atmos. 2014, 119, 7577-7598. [CrossRef]

45. Gorchakov, G.I.; Shishkov, P.O.; Kopeikin, V.M.; Emilenko, A.S.; Isakov, A.A.; Zakharova, P.V.; Sidorov, V.N.; Shukurov, K.A. Lidar-nephelometric sounding of arid aerosol. Atmos. Ocean. Opt. 1998, 11, 958-962.

46. Golitsyn, G.S.; Granberg, I.G.; Aloyan, A.E.; Andronova, A.V.; Gorchakov, G.I.; Ponomarev, V.M.; Shishkov, P.O. Study of emissions and transport of dust aerosol in Kalmykia Black Lands. J. Aerosol. Sci. 1997, 28 (Suppl. 1), S725-S726. [CrossRef]

47. Golitsyn, G.S.; Granberg, I.G.; Andronova, A.V.; Ponomarev, V.M.; Zilitinkevich, S.S.; Smirnov, V.V.; Yablokov, M.Y. Investigation of boundary layer fine structure in arid regions: Injection of fine dust into the atmosphere. Water Air Soil Pollut. 2003, 3, $245-257$. [CrossRef]

48. Chkhetiani, O.G.; Gledzer, E.B.; Artamonova, M.S.; Iordanskii, M.A. Dust resuspension under weak wind conditions: Direct observations and model. Atmos. Chem. Phys. 2012, 12, 5147-5162. [CrossRef]

49. Li, X.L.; Klose, M.; Shao, Y.; Zhang, H.S. Convective turbulent dust emission (CTDE) observed over Horqin Sandy Land area and validation of a CTDE scheme. J. Geophys. Res. Atmos. 2014, 119, 9980-9992. [CrossRef]

50. Gledzer, E.B.; Granberg, I.G.; Chkhetiani, O.G. Air dynamics near the soil surface and convective emission of aerosol. Izv. Atmos. Ocean. Phys. 2010, 46, 29-40. [CrossRef]

51. Chkhetiani, O.G.; Gledzer, E.B.; Vazaeva, N.V. Measurements and approximations for submicron-aerosol size distribution functions. Earth Space Sci. 2021, 8, e2020EA001616. [CrossRef]

52. Han, Z.W.; Ueda, H.; Matsuda, K.; Zhang, R.J.; Arao, K.; Kanai, Y.; Hasome, H. Model study on particle size segregation and deposition during Asian dust events in March 2002. J. Geophys. Res. Atmos. 2004, 109, D19205. [CrossRef]

53. Sun, J.M.; Zhang, M.Y.; Liu, T.S. Spatial and temporal characteristics of dust storms in China and its surrounding regions, 1960-1999: Relations to source area and climate. J. Geophys. Res. Atmos. 2001, 106, 10325-10333. [CrossRef]

54. Qian, Y.; Gustafson, W.I., Jr.; Fast, J.D. An investigation of the sub-grid variability of trace gases and aerosols for global climate modeling. Atmos. Chem. Phys. 2010, 10, 6917-6946. [CrossRef]

55. Shukurov, K.A.; Chkhetiani, O.G. Probability of transport of air parcels from the arid lands in the Southern Russia to Moscow region. In Proceedings of the 23rd International Symposium on Atmospheric and Ocean Optics: Atmospheric Physics, Irkutsk, Russia, 30 November; International Society for Optics and Photonics: Bellingham, WA, USA, 2017; Volume 10466, p. 104663V. [CrossRef]

56. Mikami, M.; Shi, G.; Uno, I.; Yabuki, S.; Iwasaka, Y.; Yasui, M.; Aoki, T.; Tanaka, T.; Kurosaki, Y.; Masuda, K.; et al. Aeolian dust experiment on climate impact: An overview of Japan-China joint project ADEC. Glob. Planet. Chang. 2006, 52, 142-172. [CrossRef]

57. Huebert, B.J.; Bates, T.; Russell, P.B.; Shi, G.; Kim, Y.J.; Kawamura, K.; Carmichael, G.; Nakajima, T. An overview of ACE-Asia: Strategies for quantifying the relationships between Asian aerosols and their climatic impacts. J. Geophys. Res. Atmos. 2003, 108. [CrossRef]

58. Arimoto, R.; Kim, Y.; Quinn, P.; Bates, T.; Anderson, T.; Gong, S.; Uno, I.; Chin, M.; Huebert, B.; Clarke, A.; et al. Characterization of Asian dust during ACE-Asia. Glob. Planet. Chang. 2006, 52, 23-56. [CrossRef]

59. Clerbaux, N.; Ipe, A.; De Bock, V.; Urbain, M.; Baudrez, E.; Velazquez-Blazquez, A.; Akkermans, T.; Moreels, J.; Hollmann, R.; Selbach, N. CM SAF Aerosol Optical Depth (AOD) Data Record-Edition 1. Satell. Appl. Facil. Clim. Monit. 2017. [CrossRef]

60. Zolotokrylin, A.N.; Cherenkova, E.A.; Titkova, T.B. Aridization of drylands in the european part of Russia: Secular trends and links to droughts. Izv. Ser. Geogr. 2020, 84, 207-217. [CrossRef]

61. Gubanova, D.P.; Kuderina, T.M.; Chkhetiani, O.G.; Iordanskii, M.A.; Obvintsev, Y.I.; Artamonova, M.S. Experimental Studies of Aerosols in the Atmosphere of Semiarid Landscapes of Kalmykia: 2. Landscape-Geochemical Composition of Aerosol Particles. Izv. Atmos. Ocean. Phys. 2018, 54, 1430-1448. [CrossRef]

62. Kok, J.F. A scaling theory for the size distribution of emitted dust aerosols suggests climate models underestimate the size of the global dust cycle. Proc. Natl. Acad. Sci. USA 2011, 108, 1016-1021. [CrossRef] [PubMed]

63. Gillette, D.A.; Blifford, I.H., Jr.; Fenster, C.R. Measurements of aerosol size distributions and vertical fluxes of aerosols on land subject to wind erosion. J. Appl. Meteorol. Climatol. 1972, 11, 977-987. [CrossRef] 
64. Bulygina, O.N.; Veselov, V.M.; Razuvaev, V.N.; Aleksandrova, T.M. Opisanie Massiva Srochnyh Dannyh ob Osnovnyh Meteorologicheskih Parametrah Rossii (Description of the Array of Urgent data on the Main Meteorological Parameters at Russian Stations). Database State Regist. Certif. 2014, 2014620549. Available online: http:/ / meteo.ru/data/163-basic-parameters\#

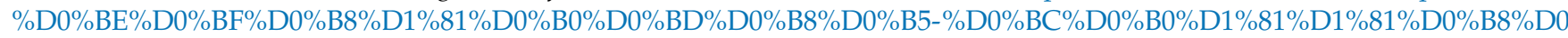
$\%$ B2 $\%$ D0 $\%$ B0- $\%$ D0 $\%$ B4\%D0\%B0\%D0\%BD $\%$ D0\%BD $\%$ D1\%8B $\% 1 \% 85$ (accessed on 27 July 2021). (In Russian)

65. RIHMI-WDS. Available online: http:/ / meteo.ru/english/climate/cl_data.php (accessed on 21 May 2021).

66. Monin, A.S.; Obukhov, A.M. Basic laws of turbulent mixing in the surface layer of the atmosphere. Contrib. Geophys. Inst. Acad. Sci. USSR 1954, 151, e187.

67. Kurgansky, M.V. On the vertical lifting of dust in a convective unstable atmospheric boundary layer. Izv. Atmos. Ocean. Phys. 2014, 50, 337-342. [CrossRef]

68. Klose, M.; Shao, Y. Large-eddy simulation of turbulent dust emission. Aeolian Res. 2013, 8, 49-58. [CrossRef]

69. Prospero, J.M. Long-range transport of mineral dust in the global atmosphere: Impact of African dust on the environment of the southeastern United States. Proc. Natl. Acad. Sci. USA 1999, 96, 3396-3403. [CrossRef]

70. Schütz, L. Long range transport of desert dust with special emphasis on the Sahara. Ann. N. Y. Acad. Sci. 1980, 338, 515-532. [CrossRef]

71. DeMott, P.J.; Cziczo, D.J.; Prenni, A.J.; Murphy, D.M.; Kreidenweis, S.M.; Thomson, D.S.; Borys, R.; Rogers, D.C. Measurements of the concentration and composition of nuclei for cirrus formation. Proc. Natl. Acad. Sci. USA 2003, 100, 14655-14660. [CrossRef] [PubMed]

72. Sassen, K.; DeMott, P.J.; Prospero, J.M.; Poellot, M.R. Saharan dust storms and indirect aerosol effects on clouds: CRYSTAL-FACE results. Geophys. Res. Lett. 2003, 30, 1633. [CrossRef]

73. Min, Q.-L.; Li, R.; Lin, B.; Joseph, E.; Wang, S.; Hu, Y.; Morris, V.; Chang, F. Evidence of mineral dust altering cloud microphysics and precipitation. Atmos. Chem. Phys. 2009, 9, 3223-3231. [CrossRef]

74. Weinzierl, B.; Ansmann, A.; Prospero, J.M.; Althausen, D.; Benker, N.; Chouza, F.; Dollner, M.; Farrell, D.; Fomba, W.K.; Freudenthaler, V.; et al. The Saharan Aerosol Long-Range Transport and Aerosol-Cloud-Interaction Experiment: Overview and selected highlights. Bull. Am. Meteorol. Soc. 2017, 98, 1427-1451. [CrossRef]

75. Hashizume, M.; Ueda, K.; Nishiwaki, Y.; Michikawa, T.; Onozuka, D. Health effects of Asian dust events: A review of the literature. Jpn. J. Hyg. 2010, 65, 413-421. [CrossRef]

76. de Longueville, F.; Ozer, P.; Doumbia, S.; Henry, S. Desert dust impacts on human health: An alarming worldwide reality and a need for studies in West Africa. Int. J. Biometeorol. 2013, 57, 1-19. [CrossRef] [PubMed]

77. Morman, S.A.; Plumlee, G.S. The role of airborne mineral dusts in human disease. Aeolian Res. 2013, 9, 203-212. [CrossRef]

78. Stein, A.F.; Draxler, R.R.; Rolph, G.D.; Stunder, B.J.B.; Cohen, M.D.; Ngan, F. NOAA's HYSPLIT atmospheric transport and dispersion modeling system. Bull. Am. Meteor. Soc. 2015, 96, 2059-2077. [CrossRef]

79. Gorchakov, G.I.; Koprov, B.M.; Shukurov, K.A. Vertical turbulent aerosol fluxes over desertized areas. Izvestiya. Atmos. Ocean. Phys. 2002, 38 (Suppl. 1), 138-147.

80. Kalnay, E.; Kanamitsu, M.; Kistler, R.; Collins, W.; Deaven, D.; Gandin, L.; Iredell, M.; Saha, S.; White, G.; Woolen, J.; et al. The NCEP/NCAR 40-year reanalysis project. Bull. Am. Meteor. Soc. 1996, 77, 437-471. [CrossRef]

81. Kistler, R.; Kalnay, E.; Collins, W.; Saha, S.; White, G.; Woolen, J.; Chelliah, M.; Ebisuzaki, W.; Kanamitsu, M.; Kousky, V.; et al. The NCEP/NCAR 50-year reanalysis: Monthly means CD-ROM and documentation. Bull. Am. Meteor. Soc. 2001, 82, 247-268. [CrossRef]

82. Wang, Y.Q. MeteoInfo: GIS software for meteorological data visualization and analysis. Meteorol. Appl. 2014, 21, 360-368. [CrossRef]

83. Shinkarenko, S.S.; Tkachenko, N.A.; Bartalev, S.A.; Yuferev, V.G.; Kulik, K.N. Dust storms in the south of the European part of Russia in September-October 2020. Sovrem. Probl. Distantsionnogo Zondirovaniya Zemli Kosm. 2020, 17, 291-296. (In Russian) [CrossRef] 